INTERNATIONAL JOURNAL OF MULTIDISCIPLINARY RESEARCH AND ANALYSis

ISSN[Online] : 2643-9875 || ISSN[Print] : 2643-9840

Volume 03 Issue 10 October 2020

DOI: 10.47191/ijmra/v3-i10-01, Impact Factor : 5.522

Page No: 138-161

\title{
Trade deficit impede Nepalese economic growth : an analysis from review perspective
}

\author{
${ }^{1 *}$ Saurav Khanal, ${ }^{2 *}$ Saugat Khanal \\ ${ }^{1}$ Bachelor of Business studies, Tribhuvan University ,Kathmandu, Nepal \\ ${ }^{2}$ Faculty of Agriculture, Agriculture and Forestry University, Rampur, Chitwan, Nepal
}

\begin{abstract}
:
The current study completely delves into the comprehensive identification, assessment, and mitigation of trade deficit in Nepal. The objective of this article is to study and analyze the growth, composition, and direction of Nepalese foreign trade along with the causes and recommendations of trade deficit. Efforts have been made to sort out the principal sources of the trade deficit in Nepal. Landlockedness, political instability, lack of export diversification, devaluation of domestic currency, lack of resources, etc. are the major causes of the trade deficit in Nepal. Nepal, being not self-reliant on factors of production, consumer goods and capital goods, needs to import goods from abroad. On another hand, Nepal's exports are heavily concentrated; both in terms of product and destination. Nepal's major trading partners are India, China, U.A.E, Bangladesh, Germany etc. During the year 2018/19, Nepal exports goods worth RS. 97 Billion And import goods worth RS. 1418 billion leading to a trade deficit of RS.1321 Billion. Nepal mainly exports readymade garments, woolen carpets, pashmina products, jute, juices, etc and imports petroleum products, gold, vehicle, machineries and so on. It is a matter of embarrassing that the value of total exports doesn't cover even the import of petroleum products. Trade deficit is acting as negative catalyst in the economic growth and GDP of a country. Nepal's job and wealth are being handed over to other countries that have taken advantage of Nepal since very long. Increased deficit has caused suppressed inflation. Import to export ratio is continuously increasing as demand/consumption is increasing and these demands could not be met by the domestic producers. During the year 2018/19, the contribution of trade on GDPofNepal is 55\%. Nodoubt, trade is an engine of economic growth. So, after analyzing barriers in the foreign trade, some of the steps to be taken are recommended which includes the development of competitive ability and enhancement of Human Resources, commodity and market diversification, formulation of strong legal framework and trade policy, incentives for the promotion of export and priority in the agricultural and hydropower sectors.
\end{abstract}

\section{KEYWORDS:}

Trade deficit, causes, export, impacts, import, Nepal, recommendations 
Trade deficit impede Nepalese economic growth : an analysis from review perspective

\section{1) INTRODUCTION}

After the adoption of globalization in Nepal, the Nepalese economy becomes a dependent economy. Nepal has entered into a trade agreement with many countries for import and export. Because of inadequate available resources, Nepal has to import a variety of goods from abroad. So, international trade has become the boon of globalization for developing countries like Nepal. In fact, International trade is the lifeblood of the global economy. All countries in the globe undergo the process of export and import. A country imports those goods or services which are not available in the country and exports those goods or services which are in excess supply in the country. In the era of today, international trade promotes economic development by bettering competitive capacity, expanding the market, and providing modern technology and machinery for the industrial and agricultural sector. We cannot deny the fact that it is also considered as engine of economic development as it has the potential to activate the sustainable and long term economic development. Until 1951 AD, Nepal's foreign trade was just restricted with India and Tibet. Soon after 1951, the trade relation extended with Japan, the USA, Germany, Malaysia, Singapore, Thailand, Kuwait, France, Bangladesh, Spain, etc. Nowadays, foreign trade is expeditiously rising but with the increase in the total volume of trade, the trade deficit is also increasing (Kafle, 2017).

Nepal, being not self-reliant in factors of production, consumer goods and capital goods, international trade is very pivotal for economic prosperity. Foreign trade is one of the outstanding sources of foreign exchange earning which is necessary to import capital goods along with other consumer goods and services that are not produced locally. GDP of a country increases when there is trade surplus (i.e. the total value of goods and services that our domestic producers sell abroad is more than the value of goods and services that domestic consumers buy). In contrary, if we consume more of the foreign goods in comparison to value of goods sold to foreigners, then trade deficit arises. In this regard, our GDP falls down.

\section{1) BACKGROUND OF THESTUDY}

Nepal, a small economy, having around 56\% (World Bank, 2019) of contribution by trade in its GDP in 2019 AD, has been confronting a trade deficit since few years. In Nepal, trend of trade deficit is continuously increasing as it has very few goods to export. In 1980s, the majority of Nepal's exports were used to be raw materials, agro-based goods, handicrafts, Blankets, cultural items like Dhaka topi, and so on in large volume but low profitable value. However, after 1990s Nepal's exports have been shifted to manufactured parts to some extent. Import is increasing in comparison to the export. Enhancement in the purchasing power of people brought by the inflow of remittance has led to the increase in import of vehicles, electronic items, jewellery, and other luxurious items; however economic in-stability and feeling of insecurity has led to the decrease in export of commodities. The amplifying and continued discrepancies between the level of export and import have produced a distressing level of trade deficit in Nepal. Over the years, export is still in the ground while import skyrocketed. Statistics shows that the total import for the F/Y 18-19 is approximately 14 times than that of export. India continued to maintain a major share in Nepal's foreign trade. After the enactment of Industrial act and liberalization in India, India's share in Nepal's total merchandise trade also increases. Diminishing growth in export compared to booming growth in import has become the matter of great concern for Nepal to benefit from Trade. The average growth in the export was $5.95 \%$ in the last decade whereas growth in import during the same period was 16.29\% (Trade and Export Promotion Centre, 2019). During the year 2014/15 and 2015/16 exports was decreased, however it again gain pace after 2016. Over the decades, import is promoted and triggered by the remittance which supports for consumption of goods and services. In the year 2018/19, import from India comprises about $65.5 \%$ of Nepal's total import. And from 
Trade deficit impede Nepalese economic growth : an analysis from review perspective

china it was $13.70 \%$. Nepal imported $20.70 \%$ from the countries other than India and China. Structurally, Nepal's economy is still highly dependent on agriculture, but the services sector is largest contributor to National GDP. Agriculture accounts for $31.7 \%$ of GDP and about $65 \%$ of employment. The structure of Nepali economy is gradually shifting away from agriculture with notable migration from rural to urban areas and overseas. Nepal is one of the most liberalized and trade dependent economies in the South Asia. The process of economic liberalization started in 1985 and started to accelerate after 1990. After becoming a member of World Trade Organization (WTO), Nepal continued to broaden the openness and pushed down tariff walls and other kinds of import restrictions.

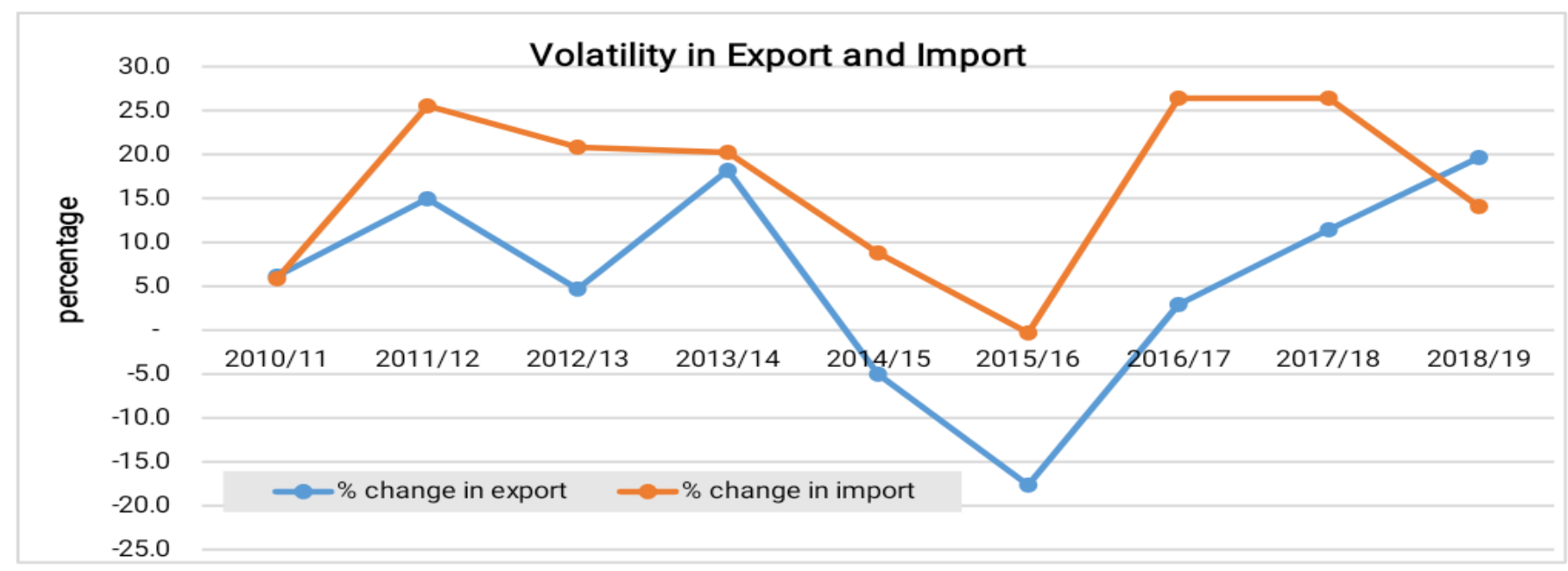

Figure 1 Volatility in Export and Import

Source: (Trade and export promotion centre, 2019)

\section{2) OBJECTIVES}

The main objective of the study was to understand the trade scenario, import-export value, and the trade deficit of Nepal. The specific objectives are to investigate the causes of trade deficit, major importing and exporting goods of Nepal, and impacts of trade deficit in different sectors. Also, the relevant solutions to the problems are also suggested in the paper.

\section{2.) MATERIALS AND METHODS}

Secondary sources of data were used during the study. Information from different journals, governmental reports, institutional websites, newspapers, articles, and documents were collected and the findings were summarized. Thus collected data were analyzed by using tools like Microsoft Excel and represent in figure, graphs, tables, and pie-charts.

\section{3.) RESULTS AND DISCUSSION}

\section{1) Causes of Trade Deficit in Nepal}

There are a number of causes for Trade deficit in Nepal. Efforts have been made to outline the theoretical framework on the basis of following determinants. These are discussed as;

\section{Geographical structure:}

Strategically, Nepal is located between two economic powerhouses; India in the East, West, and South and China in the North. Owing to landlocked geography, it has become able to export a limited number of goods only, while the import is far more. It is not directly connected with the sea route because of which it has to encounter trade barriers and so, lag behind the maritime neighbours in overall development and external trade. Due to the expensive freight and transportation cost, import cost also appears high. Owing to its Landlockedness, Nepal is in fragile condition for the reason of low trade in the global market and it prevents 
Trade deficit impede Nepalese economic growth : an analysis from review perspective

Nepal from reaping scaleeconomies.

\section{Low-Quality Goods}

Trade success results from the capacity to produce goods efficiently at a low marginal production cost, or from the ability to produce high-quality goods. Due to the lack of standard materials and skilled manpower in developing countries like Nepal, satisfactory quality of goods cannot be produced. Purchasing will of customers also falls down and export gradually slows down. The greed of middle-class farmers has encouraged them to use a higher amount of pesticides than recommended which has resulted in the agricultural products being toxic and poor quality. Many of the manufacturing industries do not use the ingredients in the proper mix leading to product deterioration. Due to such acts and carelessness of the domestic goods and service providers, Nepalese have been haunted by the thought that domestic goods are not of good quality to use. So, even Nepalese people are attracted towards the western fashionable goods. All these have an impact on overall external trade.

\section{Lack of resources}

Nepal has a diverse geographic structure comprising hills and mountains along with the plain lands. Being a small and landlocked country, it has to face scarcity of various resources like materials, capital, machinery, etc. With the available resources Nepal cannot produce goods to the extent which could serve even to its entire population. So, excess requirement needs to be imported. There is also a shortage of semi-skilled and highly skilled manpower in Nepal which hampers the pace of recovery and growth. Majority of the people belongs to middle-class family whose earning/saving equals with the expenditure. So, there arises a lack of capital for the start-up of the company which pushes the Nepalese economy backward. Due to a lack of upgraded machines and equipment which are necessary for production, factories are unable to run in the normal(full) capacity, that's why the quantity of goods produced is less than the budgeted production. In short, due to a lack of resources, an adequate amount of goods could not be produced domestically and it has to go through the external trade leading to the trade deficit.

\section{High Cost of Production}

Most of the raw materials are imported from abroad. Procurement cost is high in the import due to the involvement of transportation cost, custom duty, insurance in transit, bank charges, incidental costs and so on. Wages paid to the labour is also high. Similarly, other overhead is also high. Due to the vintage quality of machineries, preventive maintenance cost, and appraisal cost incurred to reduce internal and external failure also rises. All these expenses lead to an increase in cost of production. Nepal is a home for about only 2.80 crores of population. Nepalese economy is small. Due to low demand/consumption, quantities cannot be produced in bulk for which it cannot enjoy the benefit of economies of scale. Ultimately, the cost per unit of goods is high in comparison to the same goods that can be imported from abroad. As the goods imported from foreign seems to be cheaper, Nepal has to import goods from foreign.

\section{Lack of publicity and advertisement:}

External trade is taking different shadows and is inescapable today. This dynamic world is rapidly changing to the extent that is has been shrunk to a "Global village". This statement is true in every sense because what happens in one part of the globe has a rippling effect on some business transactions thousands of kilometers far. In the context of Nepal, it lacks marketing, publicity and advertising campaign. Nepal produces various peculiar products that carry traditional and cultural values that include handicraft goods, sweaters, and woolen clothes. Pashmina shawl is a popular brand all over the world. Despite having such branded items, Nepal doesn't advertise about the features, quality, price etc of its products in the international market because of which export of such items is low. Had advertisement been 
Trade deficit impede Nepalese economic growth : an analysis from review perspective

carried out, the exports of such products would have been increased as advertisements assists in establishing and maintaining a distinct identity, enhancing reputation, and attract new customers.

\section{Remittance}

After the signing of labor agreement with many countries, Remittance has become one of the determining sources of external finances for Nepal. Remittance assists in improving the living standard of people and diminishing poverty in the country. However, it might cause an ill situation in the trade balance. With the inflow of remittance in the country, the purchasing power of the people increases because of higher disposable income. Ultimately, the aggregate demand for consumable goods and other goods also increases, leading to an increase in imports.

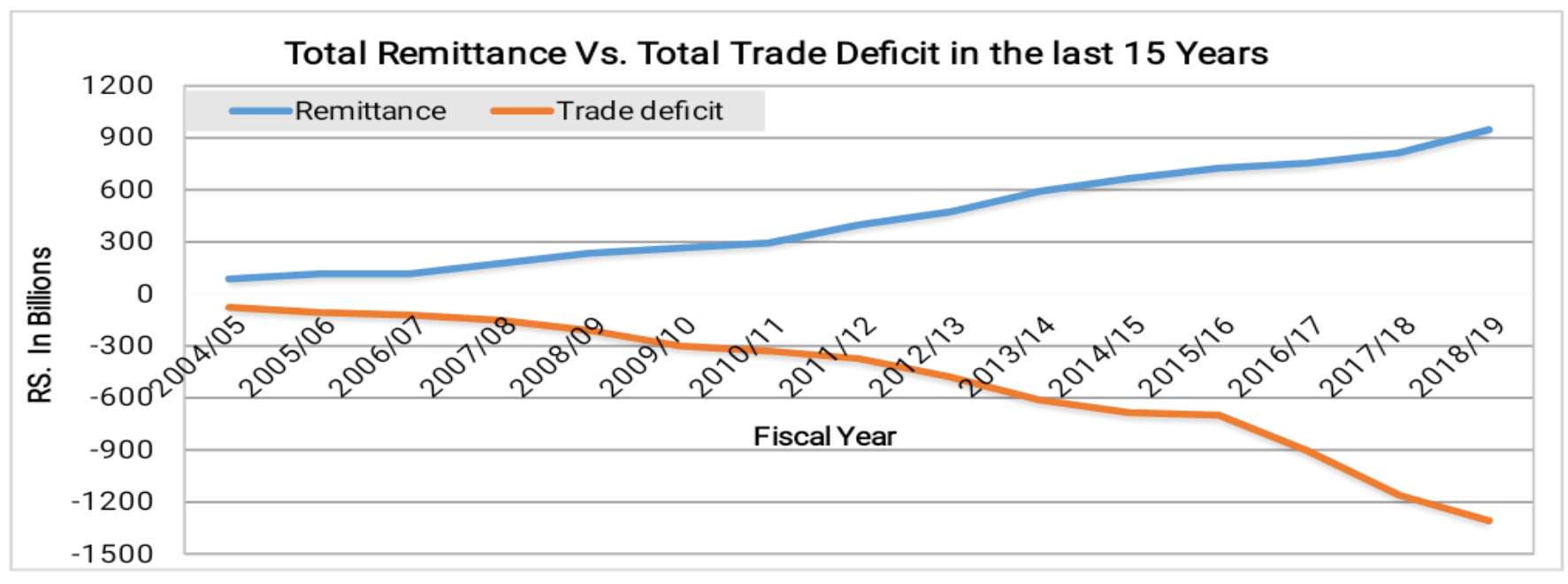

Figure 2 Total Remittance vs. Total Trade Deficit in the last 15 Years

Source: (Nepal Rastra Bank, 2019)

\section{Devaluation of Currency}

The devaluation of currency of the nation leaves negative impacts on trading. It makes export cheaper and import relatively expensive. The reason of being inelastic in demand of import and export would cause further raise in trade deficit because of devaluation. If the home currency value depreciates, then the value of import will increase and that will become heavy burden for trade balance of the country. Moreover, the depreciation of the domestic currency leads to higher cost in purchasing goods and services from foreign countries. Simply, we can say, trade deficit increases as the value of home currency falls down.

\section{Political instability}

The bothering reason of political situation in Nepal genuinely impacts on import and export factor. It influences the domestic market of the nation. The local market could not compete with outside markets because of political instability. Political stability is more crucial than economic freedom in stabilizing the balance of payments. Nepal's political condition is so unbalancing that 17 prime ministers had been changed in the last 17 years which has brought hindrances in the social and economic growth of the nation (Maps of World, 2019).

\section{2) Exports}

Nepal is a less developed country in Southern Asia. Nepal's exports are hugely concentrated; both in terms of product and destination. Hence, export diversification has become a goal of national development strategy of Nepal since the implementation of the Third Five Year Plan; 1965-70 (Nepal Planning Commission, 2016). However, limited exportable items and trade dependency, particularly with India, continue to remain a burning challenge for the Nepalese economy. On April 23, 2004, with the purpose of integrating Nepalese economy with the regional and global trading systems, Nepal joined the multi-lateral trading platform WTO 
Trade deficit impede Nepalese economic growth : an analysis from review perspective

(World Trade Organization, 2016) and entered into two regional trade agreements-Agreement on South Asian Free Trade Area (SAFTA) and Bay of Bengal Initiative for Multi-sectoral Technical and Economic cooperation (BIMSTEC) Free Trade Agreement.

Owing to similar socio-economic condition and access to sea through India only, India has become major trading partner of Nepal. However, in the last four decades, Government of Nepal has taken several measures to diversify its trade and this has led to decrease the heavy dependency on India and increases in the shares of countries other than India. The trade relation of Nepal expanded with many other countries after the downfall of tyrannical Rana regime and introduction of Democracy. Economic development in Nepal has been complicated and triggered by the instability in political scenarios which has been ranged from monarchy to being ruled by the Communist Party in 2019. With the pace of growing population and increasing consumer demands, export is also increasing significantly. During the Fiscal Year 2009/10, total export was equivalent to RS. 60.95 Billions (fig.3). It gradually increases upto 2014 AD. During the F/Y 2013/14 total amounts of export was RS. 91.36 Billions, and falls for certain years. During the F/Y 2018/19, total value of goods exported from Nepal touches RS.97.11 Billions. Nepal's export since 10 years is graphically presented as;

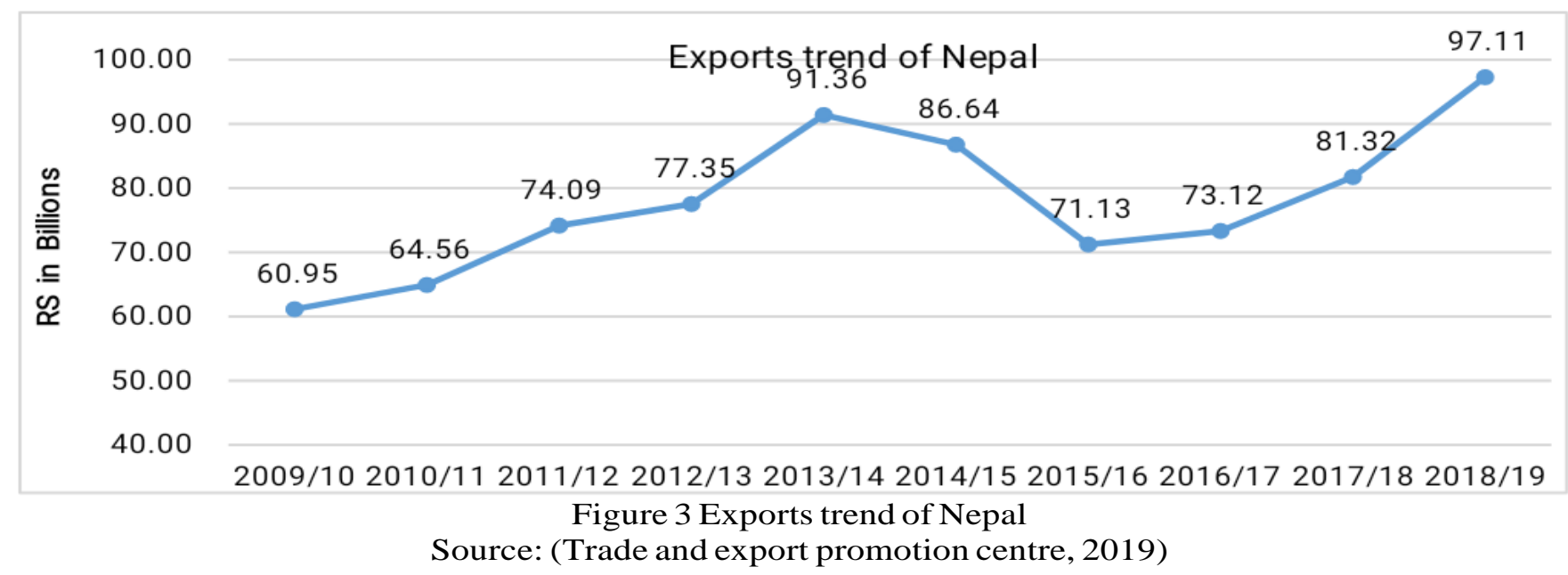

The total volume of export trade with India during the period of 2011/12 to 2018/19 is studied and observed that trade with India is in the decreasing trend. This may be the result of export diversification. During the year, a total export made to India was RS. 49.62 Billions (Table) which was nearly 67\% of the total exports. During the year 2015/16, percentage share of exports made to India falls to $56 \%$ and China cover the share of about $2 \%$. During the year 2018/19, Nepal exports goods and products to worth RS.62.73 Billion to India which is $65 \%$ of the total export. The above data is presented below;

Table 1Export trade of Nepal with India, China, and Others (Value in billions)

\begin{tabular}{llll|l|l|l|l|l|l}
\hline \multicolumn{7}{c}{ Export trade of Nepal with India, China, and Others (Value in billions) } \\
\hline Particulars & $2011 / 12$ & $2012 / 13$ & $2013 / 14$ & $2014 / 15$ & $2015 / 16$ & $2016 / 17$ & $2017 / 18$ & $2018 / 19$ \\
\hline India & 49.62 & 51 & 59.61 & 55.87 & 39.5 & 41.45 & 46.72 & 62.73 \\
China & - & 2.09 & 2.84 & 2.23 & 1.68 & 1.7 & 2.44 & 2.11 \\
Others & 24.65 & 23.83 & 29.54 & 27.23 & 28.94 & 29.9 & 32.2 & 32.27 \\
Total Exports & 74.27 & 76.92 & 91.99 & 85.33 & 70.12 & 73.05 & 81.36 & 97.11
\end{tabular}


Trade deficit impede Nepalese economic growth : an analysis from review perspective

Source: (Nepal Rastra Bank, Economic Bulletin and indicators, 2020)

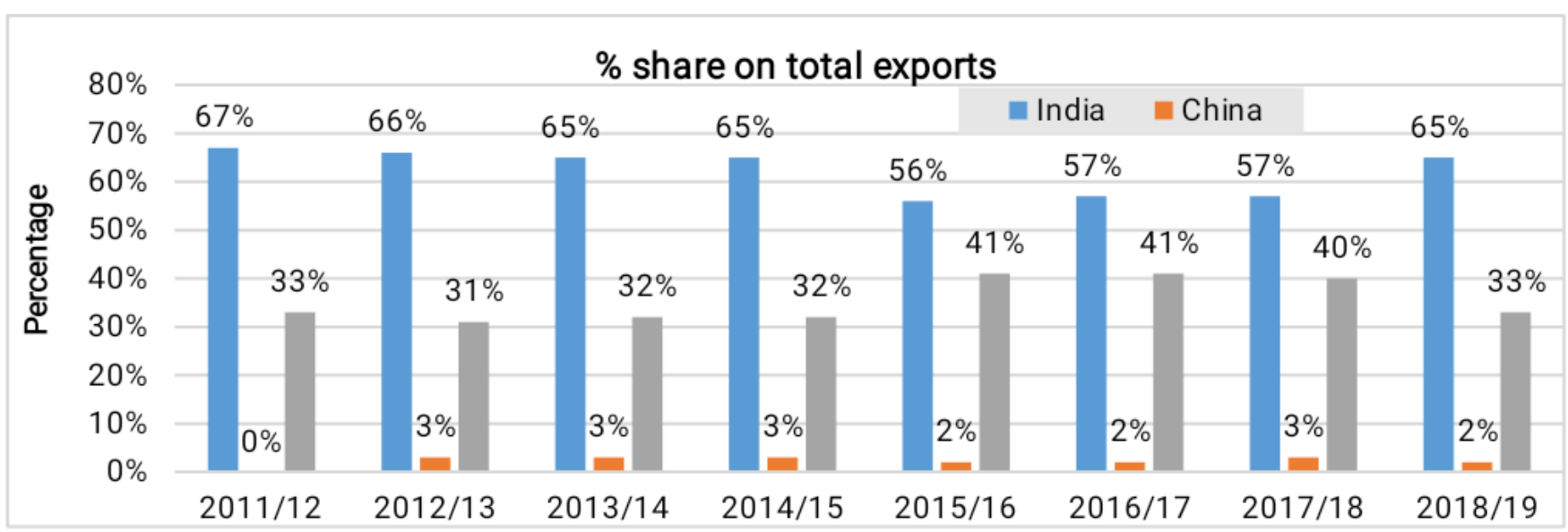

Figure 4 Percent share on total exports

Source: (Nepal Rastra Bank, Economic Bulletin and indicators, 2020)

Nepal mainly exports woolen carpets, beverages, textiles, tea, jute product, and readymade garments. With the growth of carpet and garment industries, the country's merchandise trade balance has improved to some extent. Its main export partners include India, China, US, European Union, Germany, and Bangladesh. Some of the major exports of Nepal are;

\section{Readymade Garments (RMG)}

Readymade garments sector has been developed as one of the bulkiest export items in terms of foreign exchange income and also contributing employment opportunities to large section of communities. Coats, jackets, jumpers, shirts and blouses, skirts and trousers, slacks, quilted jackets \& waistcoats etc. made from cotton are the prime categories exported from Nepal. The principal export destinations of Nepalese garments is USA followed by Canada, Germany, Netherlands, United Kingdom, Switzerland, Spain, Italy, Australia, India, etc.

Export of readymade garment once used to earn the largest chunk of foreign currency. During 2000, Nepali garment manufacturers used to export products worth Rs12 billion annually but exports started to crash after the Multi Fiber Agreement expired in January 2005 (Prasain, 2019). The Multi-fiber Arrangement (MFA) was an international trade agreement on textiles and clothing in place from 1974 till 2004. It established quotas on the amount of clothing and textile exports from developing countries to developed countries (Kenton, 2019).

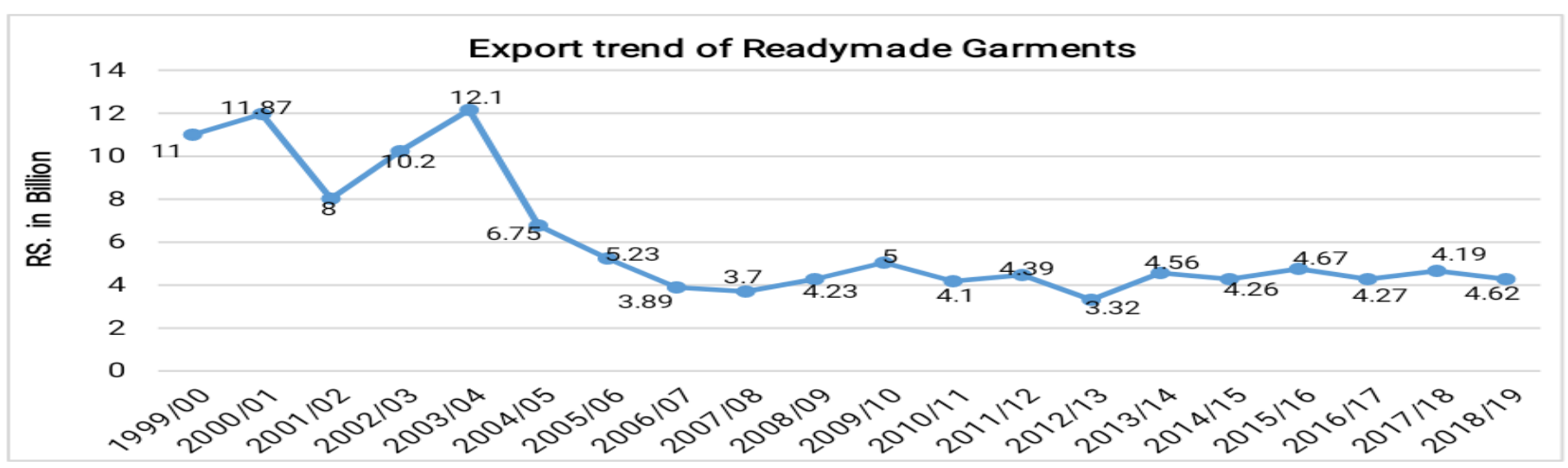

Figure 5 Export trend of Readymade Garments

Source: (Trade and Export Promotion Centre, Glimpse of Nepal's foreign trade, 2020) 
Trade deficit impede Nepalese economic growth : an analysis from review perspective

The descending movement in RMG exports was apparent after the last phase of quota elimination in 2004. The foreign market dominates the Nepalese RMG exports, accounting for more than 95 percent of the total RMG exports. Exports to India remained mild, in spite of market proximity and bilateral preferential trading arrangement between the two countries. In recent years, the share of India in total RMG exports has, however, been encouraging.

\section{Pashmina products}

Pashmina is the finest, softest, warmest and lightest wool found in nature that grows as layer in the body of Himalayan goat, locally known as Chyangra (Capra Hircus), living among 2000 meters from the sea level. Each chyangra does produce 90 grams of pashmina once a year (Sun koshi craft, 2019). Indeed, it is the best wool in the world. Pashmina is popular by different names like "Diamond Fiber" and "Soft Gold of High Asia". It is incomparable for its unique identity and charm to any other fibers. They are doubtlessly exportoriented industries. Also it is considerable export component under the handicraft goods category. The number of international export markets of Nepali Pashmina products crosses 45 out of which, USA, Italy, Canada, UK, France, J apan, Germany and India are the major ones.

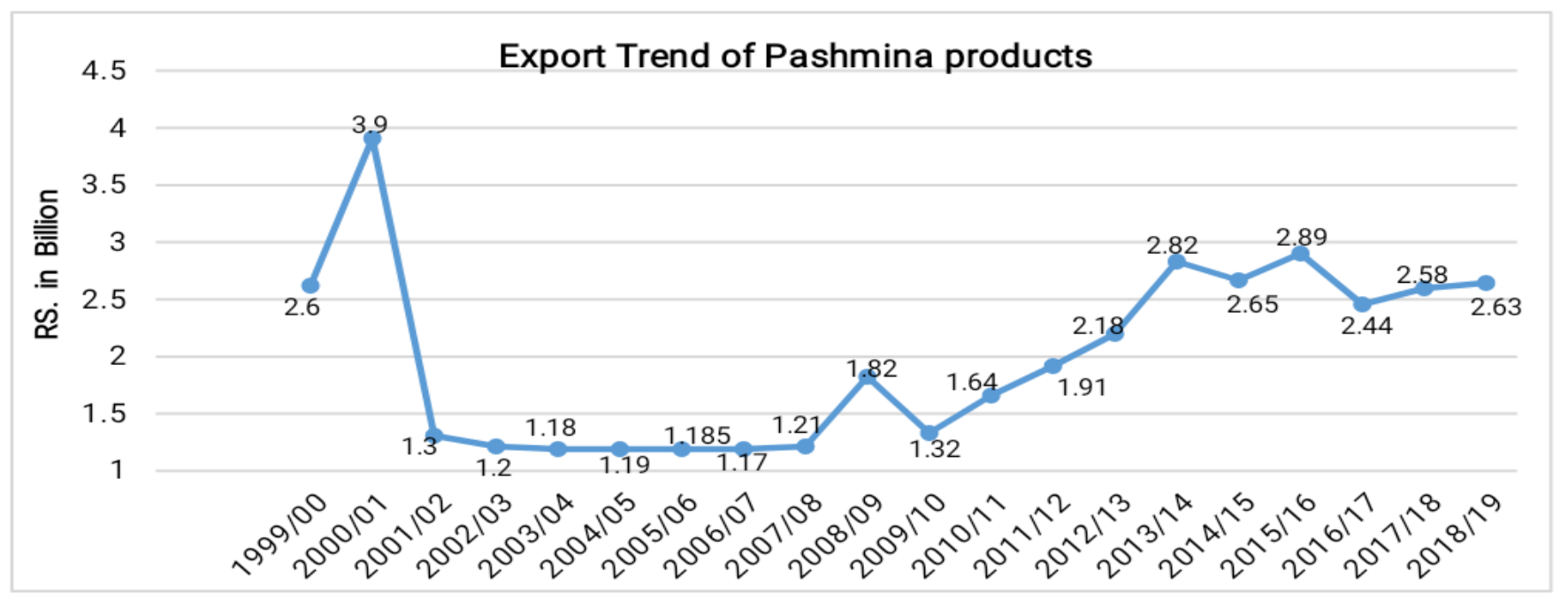

Figure 6 Export Trend of Pashmina products

Source: (Trade and Export Promotion Centre, Glimpse of Nepal's foreign trade, 2020)

\section{Woolen Carpets}

Nepalese carpets are made from highest quality fleece wool imported from Tibet, New Zealand, and Britain. The art of carpet weaving is an old practice in the mountainous region of the country. Radi, Pakhi, Bakkhu, Darhi are the popular woolen products. The production of an export quality carpet was begun with the influx of Tibetan refugees in the early sixties. The year 1960 is known as the historic year for the commercial production of the carpet in Nepal. In 1962, Nepal started the commercial shipment of the carpet with a sample consignment to Zurich, Switzerland (Nepal Carpet Manufacturer and Exporter Association, 2018)

Nepalese Carpet Industry is one of the important contributors of Nepalese economy. The export of carpet has expanded over 40 countries out of which, Germany, USA, Belgium, Britain, Turkey, Switzerland, Japan, Spain, Canada and Italy are the leading export destinations. Germany alone absorbs more than $45 \%$ of the total carpet export (Trade and Export Promotion Centre, Woolen Carpet , 2019) 
Trade deficit impede Nepalese economic growth : an analysis from review perspective

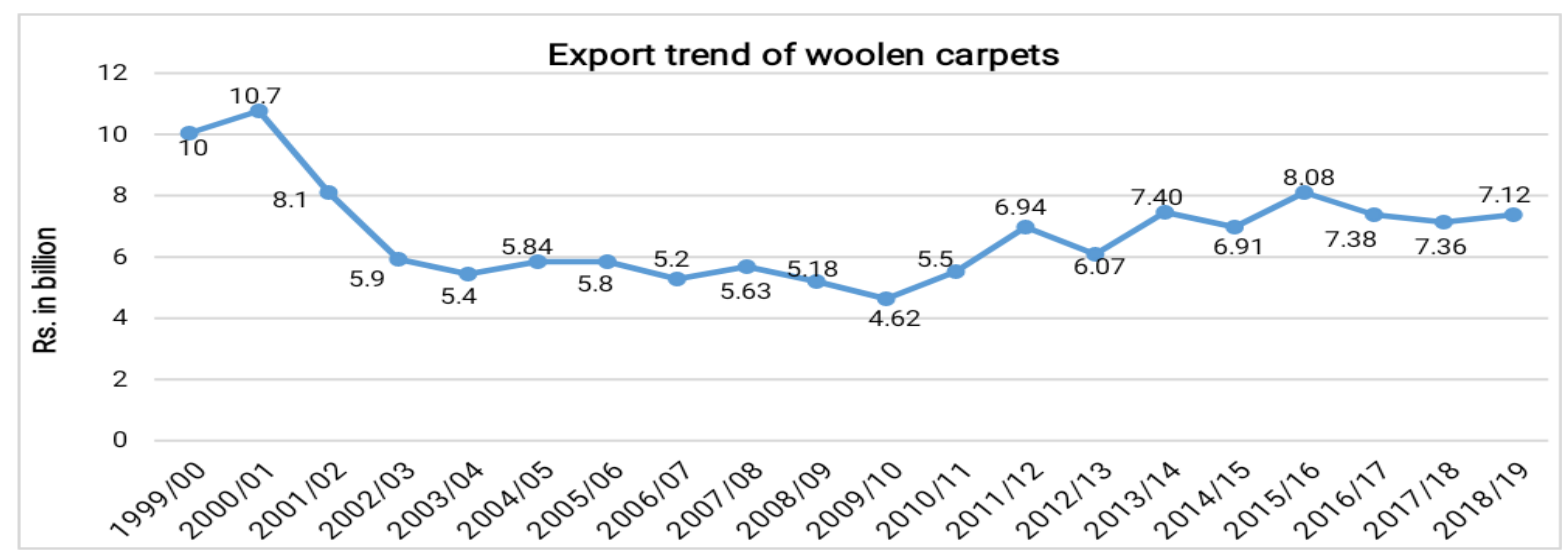

Figure 7 Export trend of woolen carpets

Others

Source: (Trade and Export Promotion Centre, Export-Import data bank, 2019)

\begin{tabular}{lllllllll} 
Products & $\mathbf{2 0 1 1 / 1 2}$ & $\mathbf{2 0 1 2 / 1 3}$ & $\mathbf{2 0 1 3 / 1 4}$ & $\mathbf{2 0 1 4 / 1 5}$ & $\mathbf{2 0 1 5 / 1 6}$ & $\mathbf{2 0 1 6 / 1 7}$ & $\mathbf{2 0 1 7 / 1 8}$ & $\mathbf{2 0 1 8 / 1 9}$ \\
\hline Pulses & 2.70 & 2.67 & 2.05 & 1.26 & 1.16 & 0.97 & 0.90 & 1.27 \\
Polyester Yarn & 3.66 & 4.74 & 5.15 & 5.02 & 3.25 & 2.82 & 3.67 & 6.16 \\
Textiles & 5.13 & 5.62 & 5.78 & 5.13 & 3.44 & 3.24 & 3.20 & 3.42 \\
Jute products & 4.07 & 4.11 & 4.30 & 4.27 & 4.25 & 4.46 & 4.64 & 5.81 \\
Thread & 2.63 & 0.11 & 0.18 & 0.18 & 0.05 & 0.03 & 0.64 & 0.76 \\
Zinc sheet & 3.34 & 4.95 & 6.18 & 4.39 & 1.94 & 2.03 & 2.78 & 2.95 \\
Juice & 3.03 & 3.80 & 4.43 & 4.77 & 3.25 & 5.06 & 4.74 & 4.55 \\
Catechu & 1.00 & - & - & - & - & - & - & -
\end{tabular}

Similarly, Gold and silver jewellery, Precious stones, Floricultural products, Medicinal herbs, Tea, Coffee, and Honey are also exported to different corners of the world.

\section{3) Imports}

Imports in Nepal averaged 44,934.88 Million NRs. from 2001 until 2020, reaching an all-time high of 1,41,240.60 Million NRs. in September of 2018 and record low of 8,000.30 Million NRs. in October of 2001 (Trading Economics, 2020). Because of the expanding population with the increased number of demands and consumptions, import is increasing very rapidly. During the year 2009/10, total value of goods imported was only NPR. 375 Billions, while during the year 2018/19, import is nearly 4 times of 2009/10 i.e NPR 1,418 Billions. Trend of import is shown graphically as;

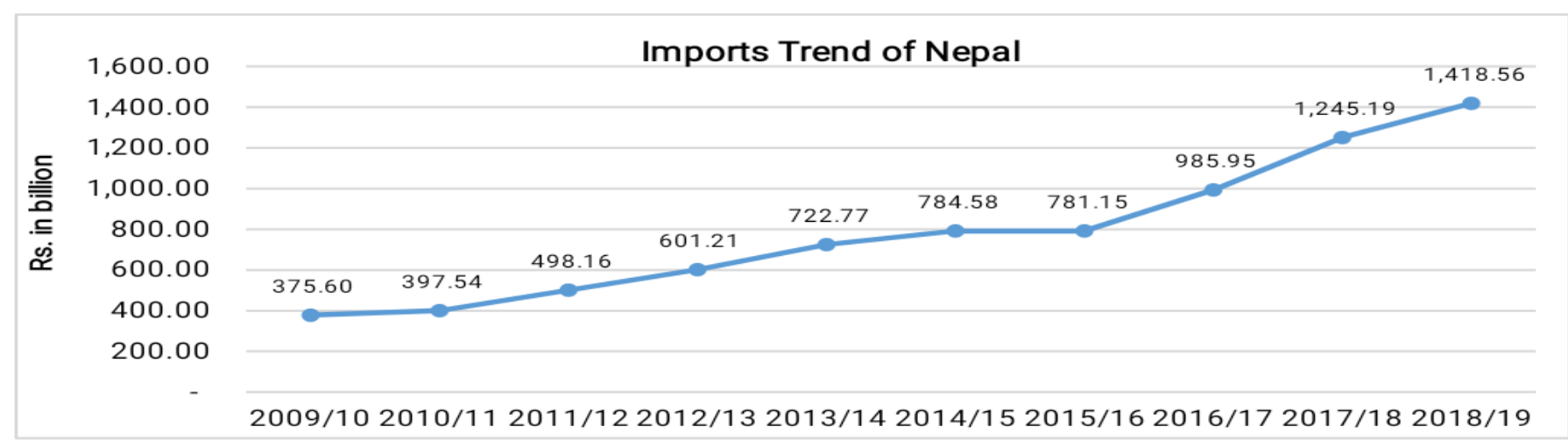

Figure 9 Imports Trend of Nepal

Source: (Trade and export promotion Centre, 2019) 
Trade deficit impede Nepalese economic growth : an analysis from review perspective

Ratio of import to export is high is Nepal due to low domestic productivity arising from Labour problems and failure to promote import substitution industrialization. The TEPC's (Trade and Export Promotion Center) statistics shows that the ratio of the country's imports to its exports stands at 14.61:1. The ratios in the fiscal years $2017 / 18$ and $2016 / 17$ were 15.31 and 13.48 respectively.

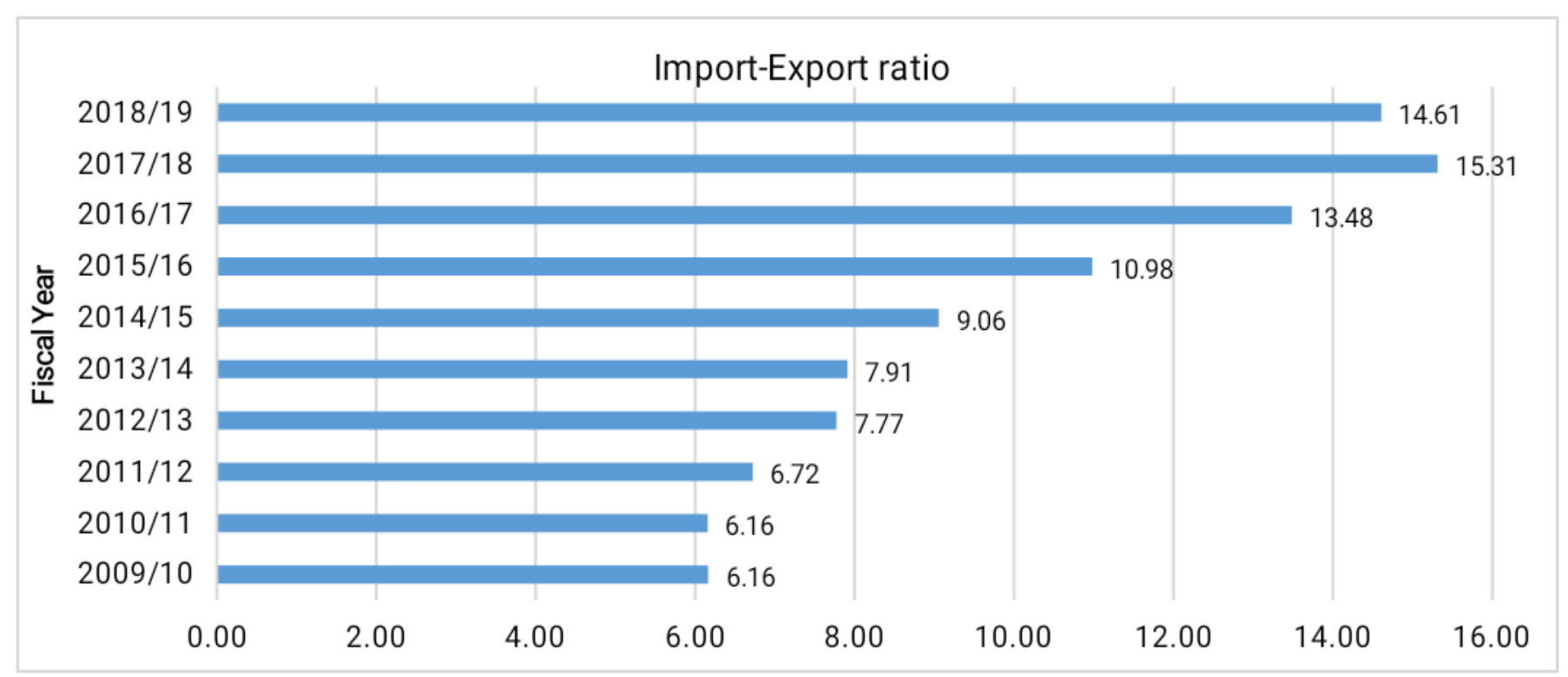

Figure 10 Import-Export ratio

Source: (Trade and export promotion centre, 2019)

The above chart indicates that Nepal is forced to divert an enormous block of its foreign exchange reserves earned from other sources such as remittance and tourism to pay for imported goods. Nepal, being surrounded by India on three sides, India has always become a major importing partner to Nepal since long back. Each year, more than $60 \%$ of the goods are imported from India.

Table 2 Import trade of Nepal with India, China, and Others (Value in billions)

\begin{tabular}{lcccccccc}
\hline \multicolumn{7}{c}{ Import trade of Nepal with India, China, and Others (Value in billions) } \\
\hline Particulars & $2011 / 12$ & $2012 / 13$ & $2013 / 14$ & $2014 / 15$ & $2015 / 16$ & $2016 / 17$ & $2017 / 18$ & $2018 / 19$ \\
\hline India & 299.39 & 367.03 & 477.95 & 491.66 & 477.21 & 633.67 & 814.1 & 917.91 \\
China & - & 62.45 & 73.32 & 100.17 & 115.69 & 127.25 & 159.99 & 205.53 \\
Others & 162.28 & 127.26 & 163.1 & 182.86 & 180.69 & 229.2 & 271.02 & 295.1 \\
Total Imports & 461.67 & 556.74 & 714.37 & 774.68 & 773.6 & 990.11 & $1,245.10$ & $1,418.54$ \\
\hline
\end{tabular}

Source: (Nepal Rastra Bank, Economic Bulletin and indicators, 2020)

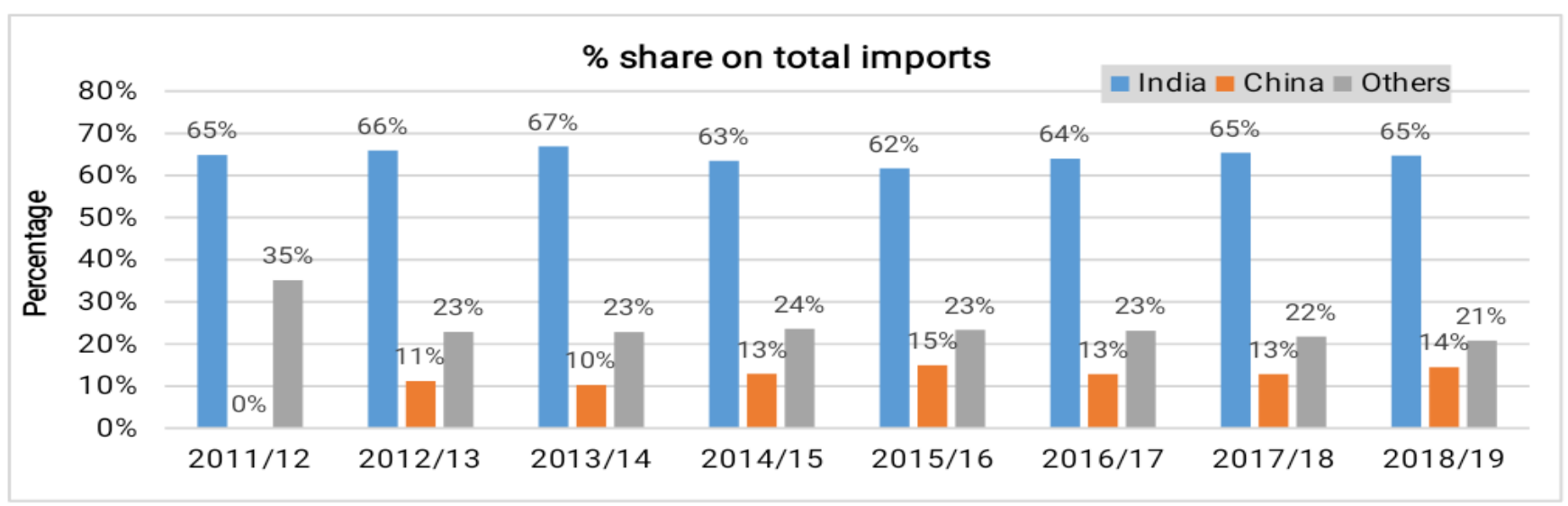

Figure 11 Percent share on total imports

Source: (Nepal Rastra Bank, Economic Bulletin and indicators, 2020) 
Nepal chiefly imports oil, gold, iron and steel, clothes, pharmaceutical products, cement, electronic appliances, food and vehicles. Some the main products imported by Nepal are;

\section{Petroleum Products}

Nepal has to rely on India for the supply and distribution of different petroleum products. The prospect of crude oil inspection has not yet been proven a feasible one. For this reason, the whole national demand is met by import alone. Till the fiscal year 2001/02, Nepal used to import petroleum products from the country other than India. From the mid of 2001/02, Nepal almost totally depended on India for the import of Petroleum products. Import of Petroleum product from India and other countries is shown in table below;

Table 3 Import value of petroleum products

\begin{tabular}{|c|c|c|c|c|}
\hline \multicolumn{5}{|c|}{ Value (in Billions) } \\
\hline Fiscal year & $\begin{array}{l}\text { Import of Petroleum } \\
\text { products from India }\end{array}$ & $\begin{array}{l}\text { Import } \\
\text { products } \\
\text { countries }\end{array}$ & $\begin{array}{l}\text { of Petroleum } \\
\text { from third }\end{array}$ & $\begin{array}{l}\text { Total imports of Petroleum } \\
\text { products }\end{array}$ \\
\hline $1999 / 00$ & 0.088 & & 7.77 & 7.858 \\
\hline 2000/01 & 0.62 & & 9.49 & 10.11 \\
\hline 2001/02 & 13.76 & & 12.5 & 26.26 \\
\hline $2002 / 03$ & 18.81 & & 0.29 & 19.1 \\
\hline $2003 / 04$ & 20.17 & & 0.29 & 20.46 \\
\hline 2004/05 & 26.39 & & 0.21 & 26.6 \\
\hline 2005/06 & 33.66 & & 0.55 & 34.21 \\
\hline $2006 / 07$ & 33.57 & & 0.57 & 34.14 \\
\hline 2007/08 & 40.82 & & 0.52 & 41.34 \\
\hline 2008/09 & 41.41 & & 0.96 & 42.37 \\
\hline $2009 / 10$ & 51.61 & & 1.69 & 53.3 \\
\hline $2010 / 11$ & 75.08 & & 1.66 & 76.74 \\
\hline $2011 / 12$ & 92.26 & & 1.68 & 93.94 \\
\hline $2012 / 13$ & 107.14 & & 2.26 & 109.4 \\
\hline $2013 / 14$ & 131.74 & & 1.82 & 133.56 \\
\hline $2014 / 15$ & 110.06 & & 2.03 & 112.09 \\
\hline $2015 / 16$ & 65.61 & & 3.12 & 68.73 \\
\hline $2016 / 17$ & 118.92 & & 2.5 & 121.42 \\
\hline $2017 / 18$ & 170.13 & & 2.11 & 172.24 \\
\hline $2018 / 19$ & 213.36 & & 2.4 & 215.76 \\
\hline
\end{tabular}

Source: (Nepal-India Chamber of Commerce and Industry, 2019)

Nepal Oil Corporation (NOC) is a monopoly trading company that imports, stores, and distributes various petroleum products. Since 10 years back, "Total imports of petroleum products" is exceeding "The total exports of Nepal". 
Trade deficit impede Nepalese economic growth : an analysis from review perspective

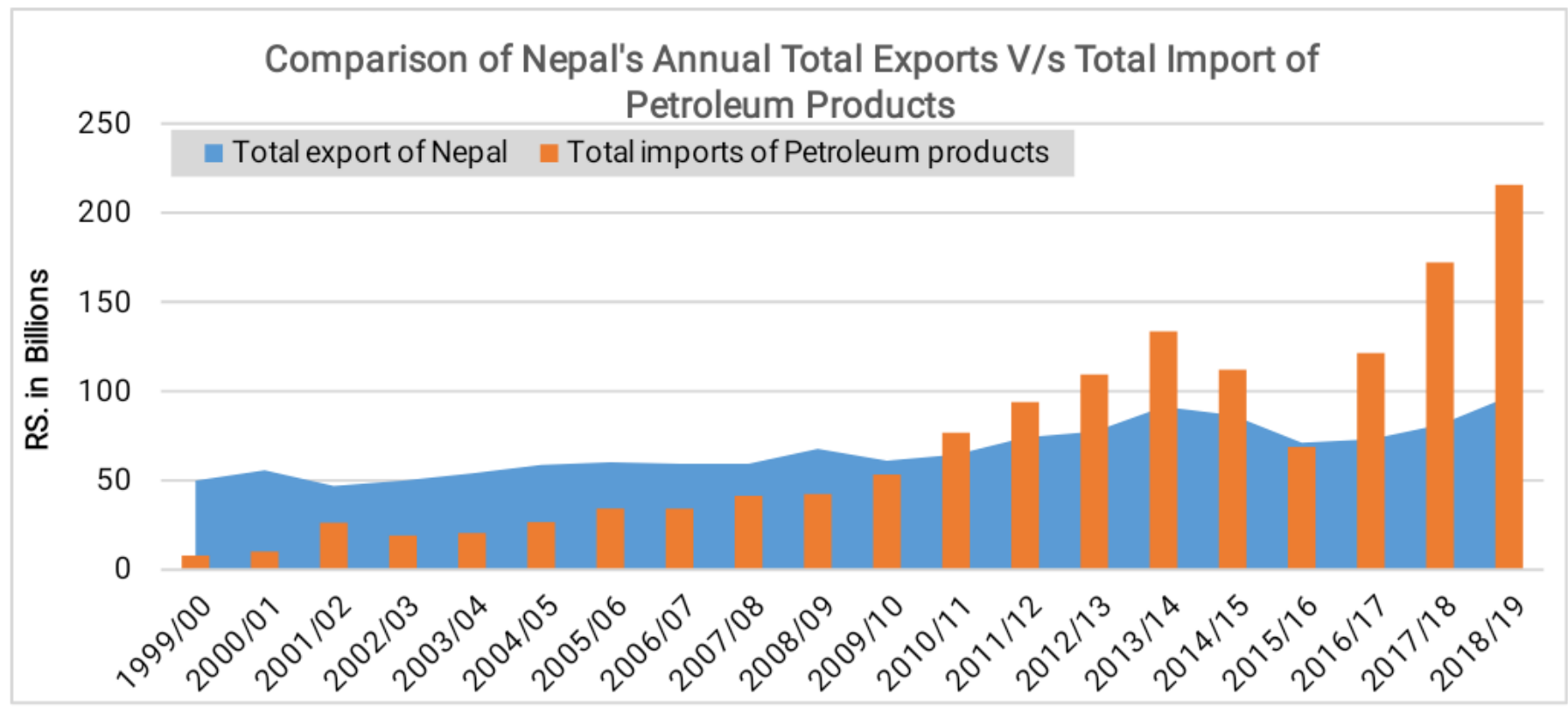

Figure 12 Nepal's Annual Total Exports V/s Total Import of Petroleum Products

\section{Gold}

Source: (Nepal-India Chamber of Commerce and Industry, 2019)

Gold has become one of the major imported items. Gold has been trusted as a wealth- preserving commodity that has held its value even during financial crisis. Now-a-days, gold has become a part of luxurious life. So, with the increase in purchasing power led by the increase in personal disposable income, demand of Gold is also increasing. All these demands are met from import.

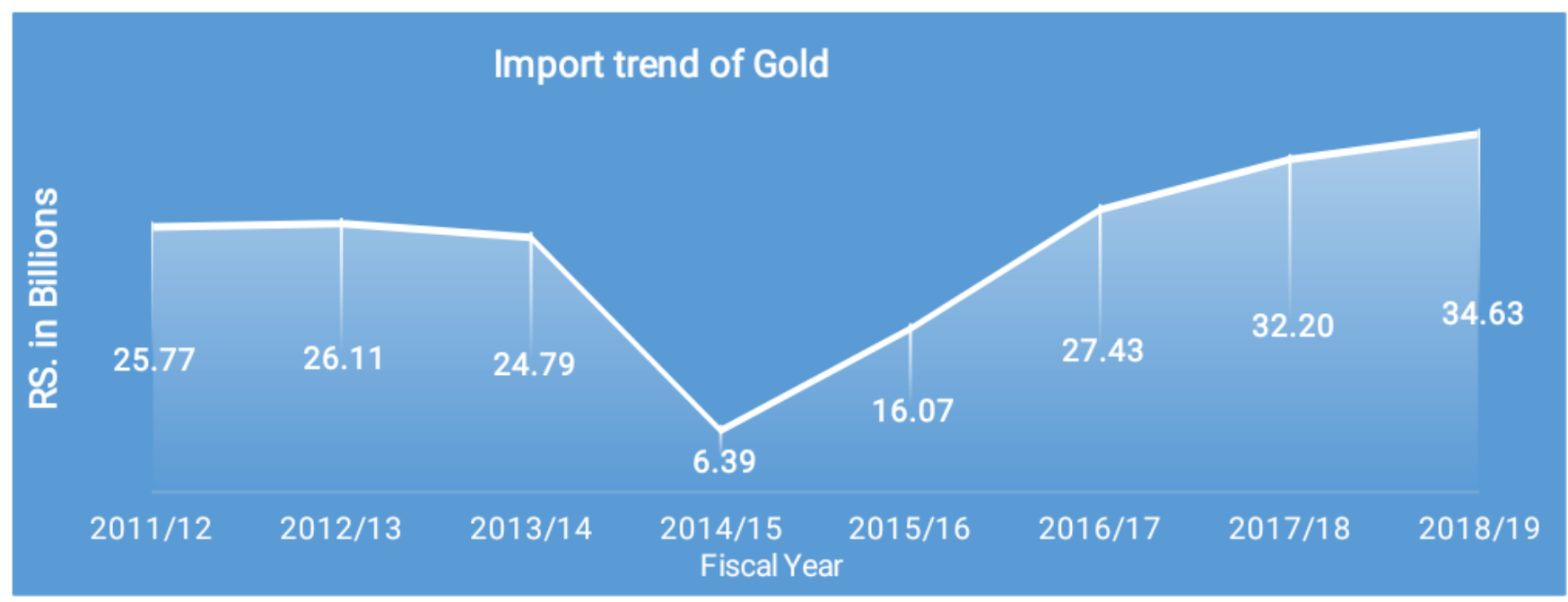

Figure 13 Import trend of Gold

Source: (Nepal Rastra Bank, Economic Bulletin and indicators, 2020)

\section{Vehicle and Spare Parts}

Data collected from 1989 to 2017 show that the country imported a total of 3.2 million vehicles in the last three decades (New Business Age, 2019). Price of Vehicles in Nepal is astronomically high as they are subject to Extravagant $288 \%$ of import tax (Benjamin J. Loecken, 2018). So, it has become very difficult for middle class family to afford four wheel vehicles. 


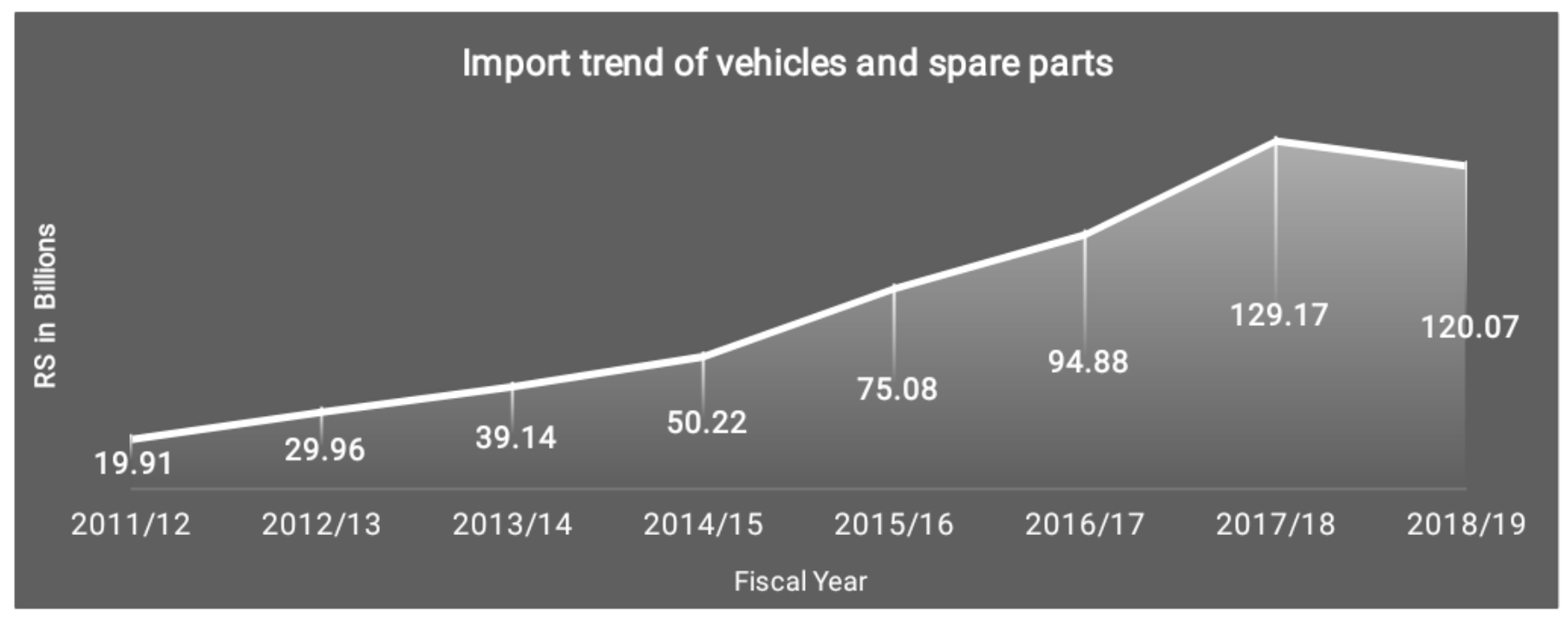

Figure 14 Import trend of vehicles and spare parts

Source: (Nepal Rastra Bank, Economic Bulletin and indicators, 2020)

\section{Others}

Other products which are imported from different countries are;

Table 4 Import of different products

\begin{tabular}{|c|c|c|c|c|c|c|c|c|}
\hline \multicolumn{9}{|c|}{$\begin{array}{l}\text { Value( in } \\
\text { Billions) }\end{array}$} \\
\hline Major Imports & $\begin{array}{l}2011 / 1 \\
2\end{array}$ & $\begin{array}{l}2012 / 1 \\
3\end{array}$ & $\begin{array}{l}2013 / 1 \\
4\end{array}$ & $\begin{array}{l}2014 / 1 \\
5\end{array}$ & $\begin{array}{l}2015 / 1 \\
6\end{array}$ & $\begin{array}{l}2016 / 1 \\
7\end{array}$ & $\begin{array}{l}2017 / 1 \\
8\end{array}$ & $\begin{array}{l}2018 / 1 \\
9\end{array}$ \\
\hline $\begin{array}{l}\text { Machinery and } \\
\text { parts }\end{array}$ & 15.54 & 20.44 & 26.74 & 33.17 & 33.91 & 43.48 & 69.08 & 78.42 \\
\hline M.S Billet & 20.01 & 22.3 & 24.68 & 26.34 & 22.66 & 46.51 & 57.94 & 66.96 \\
\hline $\begin{array}{l}\text { Electrical } \\
\text { equipment }\end{array}$ & 14.32 & 13.27 & 15.77 & 21.73 & 22.95 & 24.46 & 29 & 43.75 \\
\hline Medicine & 12.36 & 15.|99 & 18.52 & 23.64 & 28.76 & 25.46 & 29.79 & 33.07 \\
\hline $\begin{array}{l}\text { Telecommunicatio } \\
\text { n parts }\end{array}$ & 8.46 & 14.4 & 14.59 & 19.25 & 23.48 & 31.13 & 32.88 & 26.08 \\
\hline $\begin{array}{l}\text { Cold rolled sheet in } \\
\text { coil }\end{array}$ & 7.47 & 2.69 & 6.53 & 7.15 & 6.97 & 5.03 & 10.26 & 9.85 \\
\hline $\begin{array}{l}\text { M.S wires, rods, } \\
\text { Bars }\end{array}$ & 6.9 & 4.09 & 6.48 & 5.39 & 7.89 & 9.26 & 14.29 & 17.18 \\
\hline
\end{tabular}

Source: (Nepal Rastra Bank, Economic Bulletin and indicators, 2020)

\subsection{Trade Deficit}

Trade deficit, simply, is the amount by which cost of a country's imports exceeds the value of imports. Trade deficit is also called as Negative Balance of Trade.

Mathematically, Trade deficit = Value of goods imported - Value of goods exported

The trade "balance" of a region shows the difference between what it earns from its exports and what it pays for its imports. If this value is in negative i.e. the total value of goods imported by a region is more than the total value of goods exported by that region, then it shows the condition of "trade deficit". A trade deficit means generally can mean two things-Firstly, that the demand in the domestic economy is not being fulfilled by the domestic producers. Secondly, deficit implies the lack of competitiveness of the local industry (Udit Misra, 2019).

Because of low export performance, Nepal is fronting the complication of rapidly increasing trade deficit. Nepal is also unsuccessful to broaden its trade in terms of countries and commodities. Owing to rising imports of goods over slower exports, country's trade deficit has been expanding for a long time. Due to 
Trade deficit impede Nepalese economic growth : an analysis from review perspective

current adoption of double-edged policy of substituting imports and increasing exports by Nepal government, the growth rate of merchandise import has been falling and export part has been improving since last few months of fiscal year 2018/19. But, while going through the trade history of Nepal, Nepal has never been in trade surplus. Trade deficit has always been a shadow of Nepalese trade economy. Implications of trade deficit depend on impacts of production, employment, and how the deficits are financed. Nepal's import, export and trade deficit of last 10 years is graphically presented as;

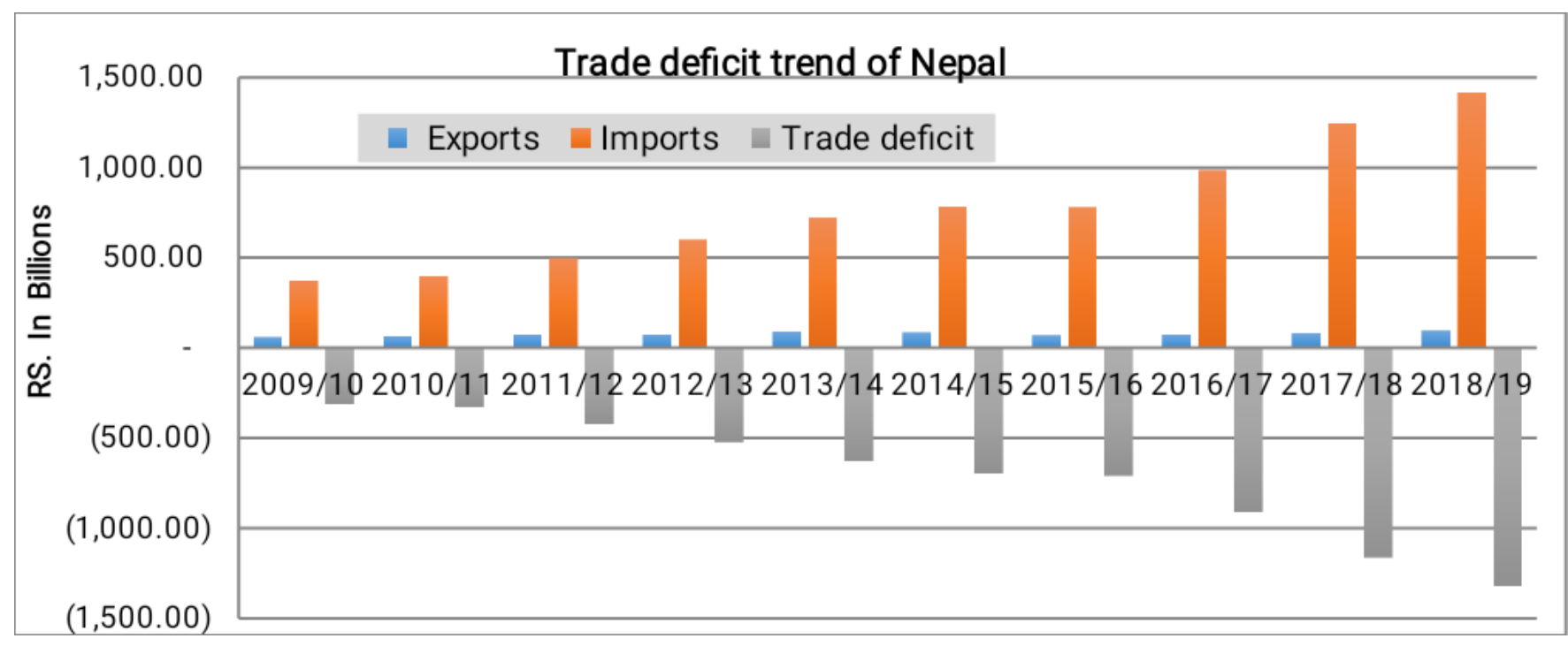

Figure 15 Trade deficit trend of Nepal

Source: (Trade and Export Promotion Centre, Glimpse of Nepal's foreign trade, 2020)

\section{4) Impacts of Trade Deficit on Nepalese economy}

Trade surpluses are no assertion of economic health, and trade deficits are no guarantee of economic weakness. Nepal is one of the economically struggling sovereign nations. The trade deficit is rising at an annual average rate of at least $13 \%$, which warns that if not adequately offset by export promotion or import substitution, will double in the next few years and quadruple in a decade. Even if we had a very effective strategy and institutional arrangements in the nation, enough researched market studies and cautiously identified potential export products that have both comparative and competitive advantages which, say, are able to offset the deficit of at least $\$ 2$ billion per annum, it will take at least a decade only to bisect the imbalance (Achyut Wagle, 2018). Some impacts brought by Trade Deficit on economy are described as;

\section{Impact of Trade Deficit on National Income}

Using the expenditure approach, National income can be represented as follows (Investopedia, 2019)

National Income $=\mathrm{C}+\mathrm{I}+\mathrm{G}+(\mathrm{X}-\mathrm{M})$

Where, $\mathrm{C}=$ Consumer spending on Goods and Services I = Investor spending on Business Capital Goods

$\mathrm{G}=$ Government spending on Public Goods and Services $\mathrm{X}=$ Exports

$\mathrm{M}=$ Imports

If value of imports exceeds value of exports, there arises a negative impact on the value of national income. So, trade deficit reduces the national income.

\section{Impacts of Trade Deficit on Gross Domestic Product}

Trade deficit is impacting on GDP of Nepal. Trade surplus helps in increasing GDP, while in contrary trade deficit decreases GDP of a nation. The negative results on GDP arise because of exceeding import demands over export earnings. Large growth in trade deficit results in decreasing demands of overall domestic goods and services. Balance of trade is one of the aspects of a country's GDP. If domestic consumers spend more 
Trade deficit impede Nepalese economic growth : an analysis from review perspective

on foreign products than domestic producers sell to foreign consumers, trade deficit occurs. If maximum of the consumer demands is met by the export, it means domestic producers are not capable enough to satisfy domestic demands. Similarly, trade deficit brings inflation in the economy which causes loss of aggregate demand. Trade deficit leads to loss of jobs in home-based industries, may contribute to regional decline, and structural unemployment problems. All these cause slower real GDPgrowth.

\section{Impact of Trade deficit on Interest rates}

The countries with more trade deficits usually have higher interest rates than those with surplus or balanced trade (Batra \& Beladi, 2013). High interest rate tends to lead to a reduction in net exports (Exports-Imports). And negative exports means trade deficit.

Interest rate is also increased to prevent the domestic currency from being devalued and ultimately increases the value of Exports leading to reduce in Trade deficit. On the other hand, trade deficit rises inflation in the county of import. Inflation can be controlled by reducing money supply in the economy. Interest rate is increased to reduce money supply. So, in general, and being skeptic on cause and effect, it can be said that a tendency towards balance of payments deficit might commonly co-exist with interest rates being higher than would otherwise be thecase.

\section{Impact of trade deficit on Price of commodities}

Increasing deficit is a sign of suppressed inflation, as domestic consumption and investment overtake the growth in the economy's productive capacity. When domestic demand/consumption is higher than the supply/production of domestic producer, then goods or services are imported. According to (Tejvan Pettinger, 2017), rise of import causes a depreciation of home currency which ultimately tends to increase inflationary pressure because;

- Imports become moreexpensive

- $\quad$ Exports and AD increase causing demand-pull inflation

- With more competitive exports, firms have less incentive to cut costs

Likewise, import cost is high due high transportation cost, insurance cost, incidental cost and other factors. So, trade deficit leads the price of commodities to be high.

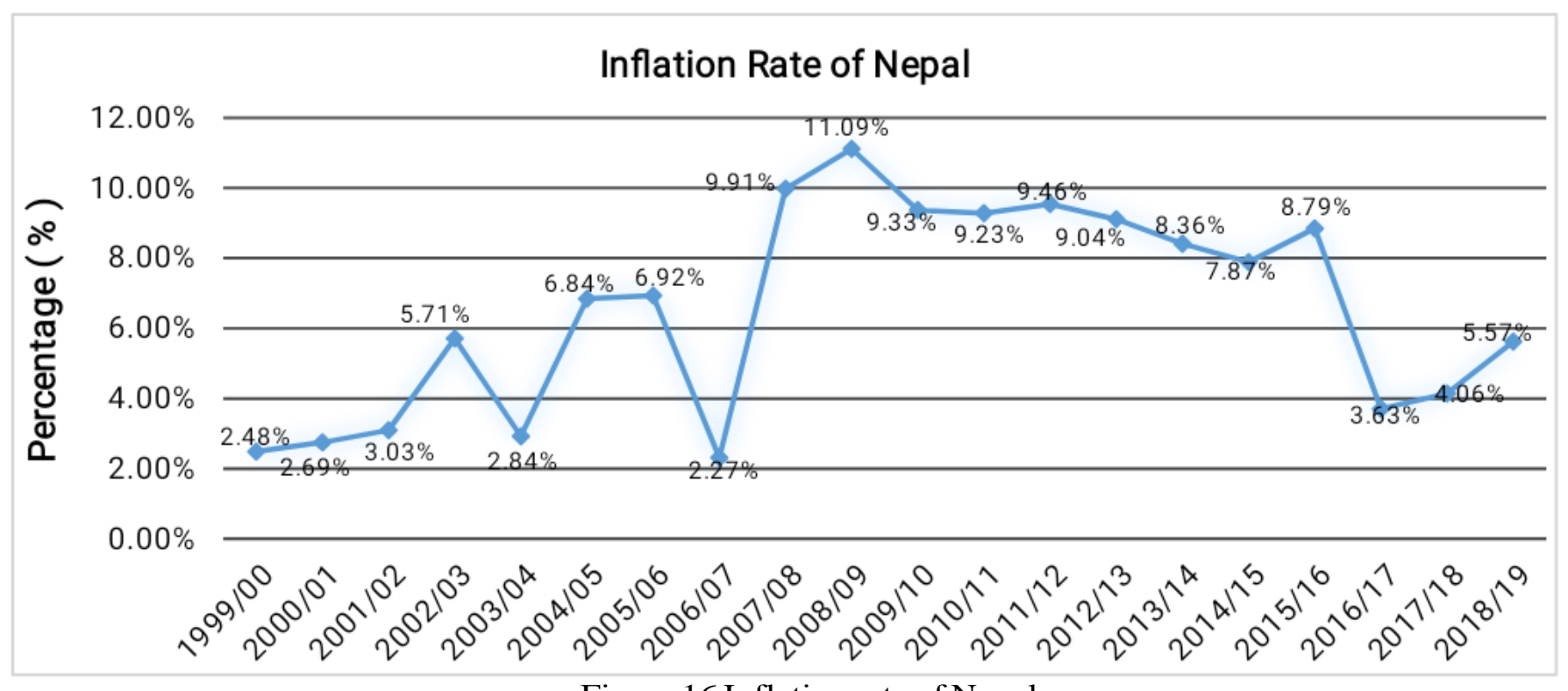

Figure 16 Inflation rate of Nepal

Source: (Macro trends, 2020) 


\section{Impact of Trade deficit on Employment}

Nepal has a trade deficit of RS.1321 Billion during the year 2018/19. Nepal's jobs and wealth are being given to other countries that have taken advantage of Nepal for years. The philosophy of this argument is that if Nepalese buy goods from foreign rather than domestically, it will cause greater demand abroad and jobs will shift where the goods are produced, leading to less employment in the country with trade deficit.

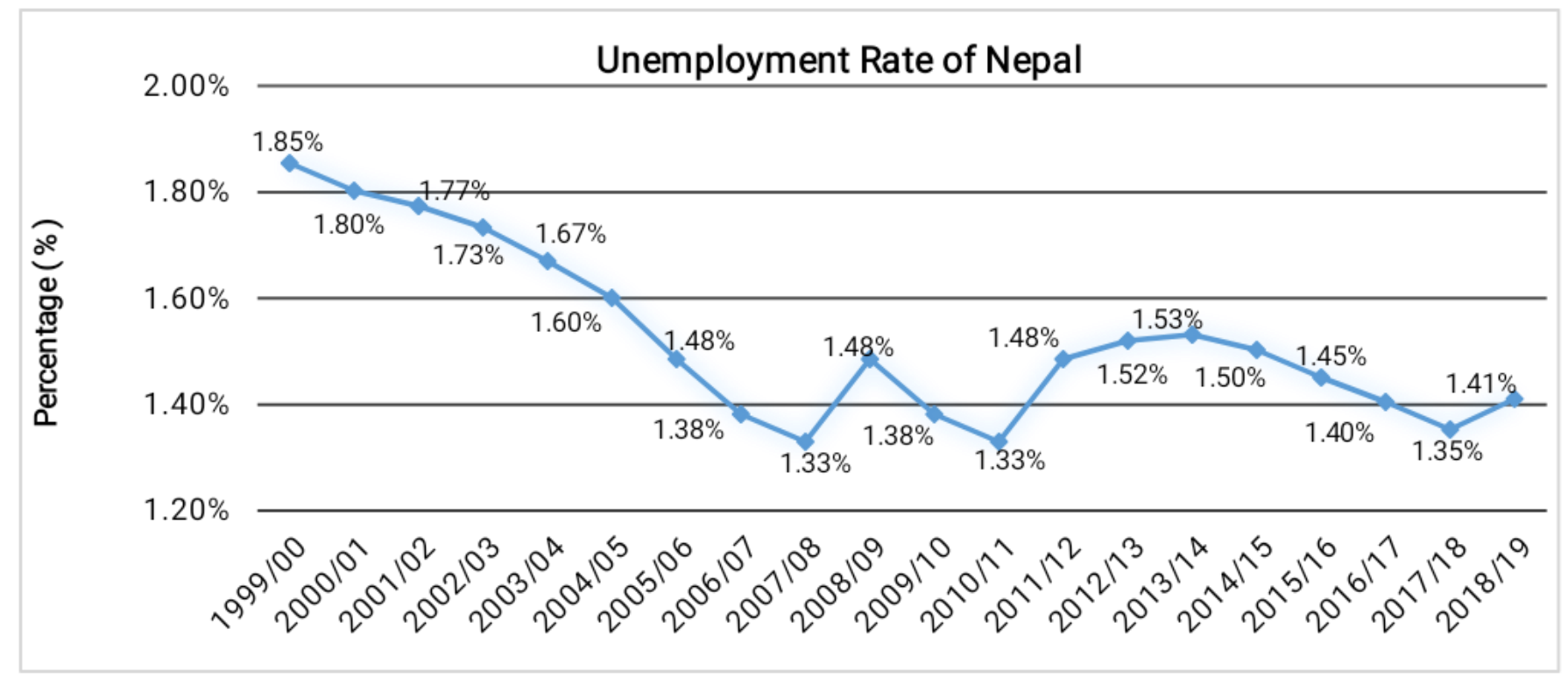

Figure 17 Unemployment Rate of Nepal

Source: (Statistica, 2020)

\subsection{Contribution of Trade on GDP of Nepal}

Trade is decisive to developing and least-developed (LDCs) for a variety of reasons. Essentially, it is often the dominant mechanism for attaining the benefits of globalization. Countries triumph when they gain market access for their exports and new technology through international transfers, and when heightened competitive pressure improves the allocation of resources. Participation in external trade provides number of benefits to the developing countries. They may achieve benefit through resource allocation according to comparative advantage; the profiteering of economies of scale and enhanced capacity utilization; modernization in technology; increases in domestic savings and foreign direct investment; and raised employment (Balassa, 1989). Trade has vital role in GDP and economic growth of nation.

Nation's balance of trade is positively affected by exports and adversely affected by imports. A trade surplus is a positive balance of trade, and trade deficit is a negative balance of trade. Due to the balance of trade being notably added to the computation of the nation's gross domestic product using the expenditure method, trade surpluses are contributions and trade deficits are "drags" upon their nation's GDP; however, foreign made goods sold (e.g., retail) contribute to total GDP (Investopedia, Expenditure method, 2019) (Bureau of Economic analysis, 2020) 
Trade deficit impede Nepalese economic growth : an analysis from review perspective

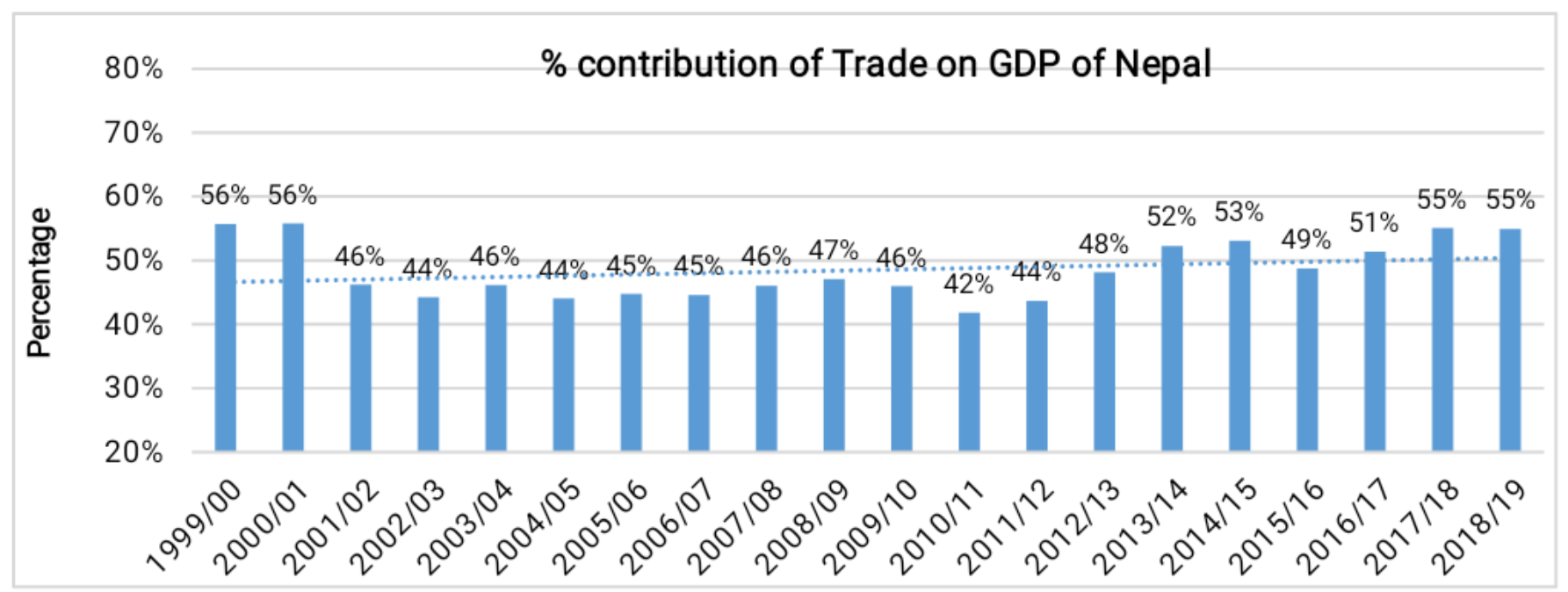

Figure 18 contribution of Trade on GDP of Nepal

Source: (World bank, 2020)

The trade to GDP ratio is an indicator of the importance of External trade in the economy of a country. It is used as an index of the openness of a country to external trade. During the year 2018/19, contribution of trade on GDP was 55\%. As of 2018/19, country's exports of goods and services as percentage of GDP is $8.9 \%$ and imports of goods and services as percentage of GDP is $46.3 \%$.

Table 5 Nepal's Trade Balance with SAARC countries

\begin{tabular}{|c|c|c|c|c|c|c|}
\hline \multicolumn{7}{|c|}{ Nepal's Trade Balance with SAARC countries in FY 18/19 (Value in million) } \\
\hline \multirow[b]{2}{*}{ SAARC country } & \multicolumn{2}{|c|}{ Export } & \multicolumn{2}{|c|}{ Import } & \multirow[b]{2}{*}{ Trade balance } & \multirow[b]{2}{*}{ Total trade } \\
\hline & Value & $\begin{array}{l}\% \\
\text { share }\end{array}$ & Value & $\%$ share & & \\
\hline India & 62,732 & 0.976 & 917,909 & 0.993 & $-855,177$ & 980,641 \\
\hline Afghanistan & 23 & 0 & 9 & 0 & 14 & 32 \\
\hline Bangladesh & 1,294 & 0.02 & 4,242 & 0.005 & $-2,948$ & 5,536 \\
\hline Bhutan & 162 & 0.003 & 1,673 & 0.002 & $-1,511$ & 1,835 \\
\hline Maldives & 7 & 0 & 1 & 0 & 6 & 8 \\
\hline Pakistan & 54 & 0.001 & 642 & 0.001 & -588 & 696 \\
\hline Sri Lanka & 8 & 0 & 276 & 0 & -268 & 284 \\
\hline Total & $64,280.00$ & 100 & $924,751.60$ & 100 & $-860,471.60$ & $989,031.60$ \\
\hline
\end{tabular}

Source: (Nepal Rastra Bank, Economic Bulletin and indicators, 2020)

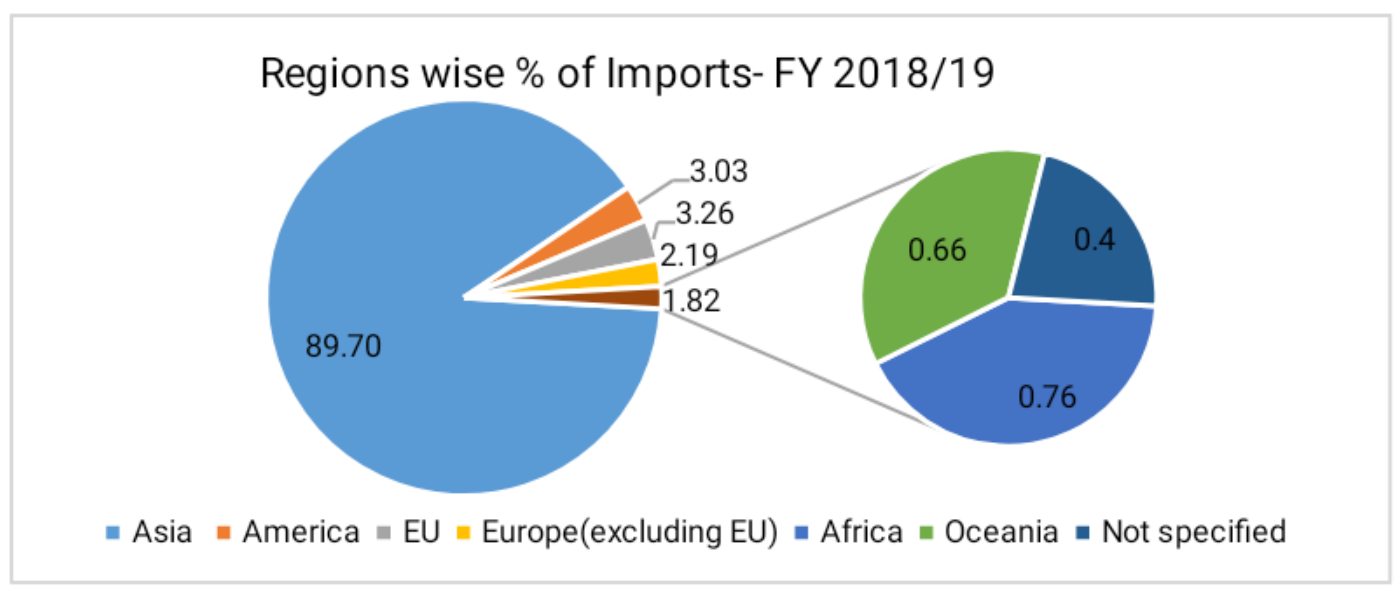

Figure 19 Regions wise \% of Imports- FY 2018/19 
Trade deficit impede Nepalese economic growth : an analysis from review perspective

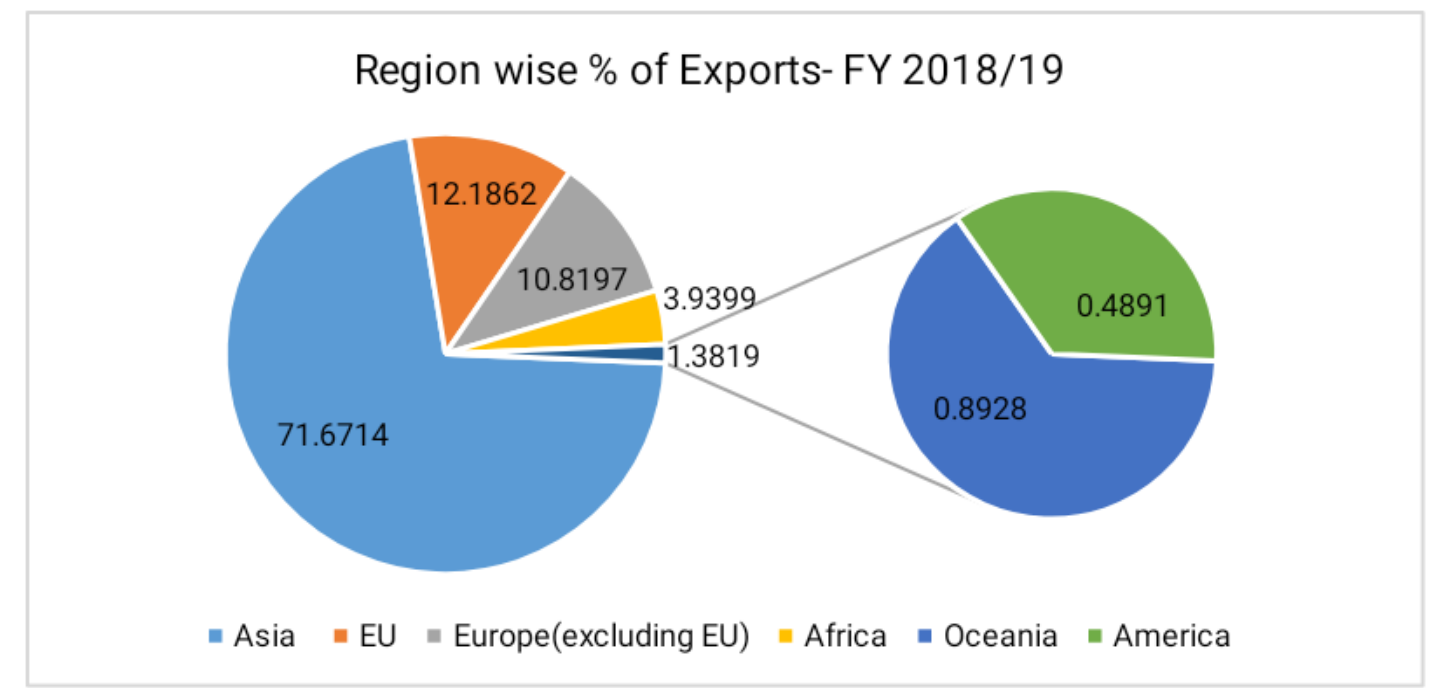

Figure 20 Region wise \% of Exports- FY 2018/19

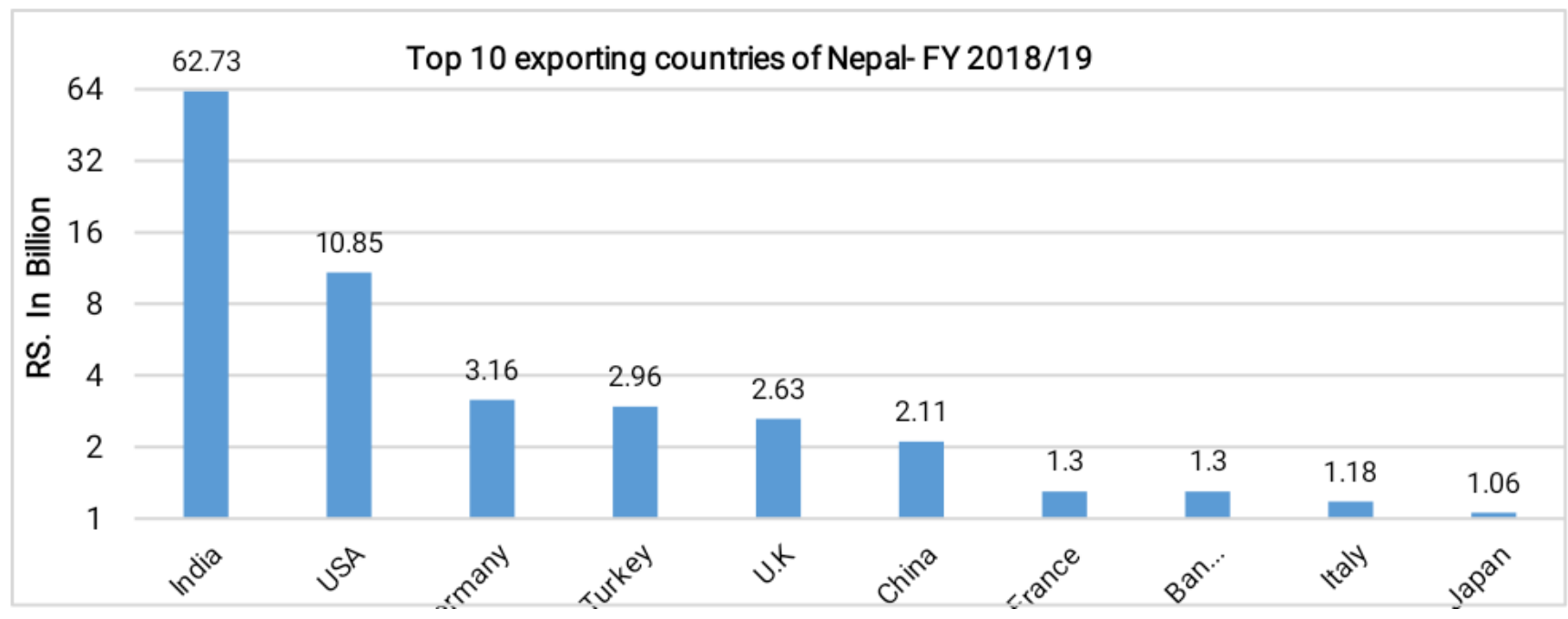

Figure 21 Top 10 exporting countries of Nepal- FY 2018/19

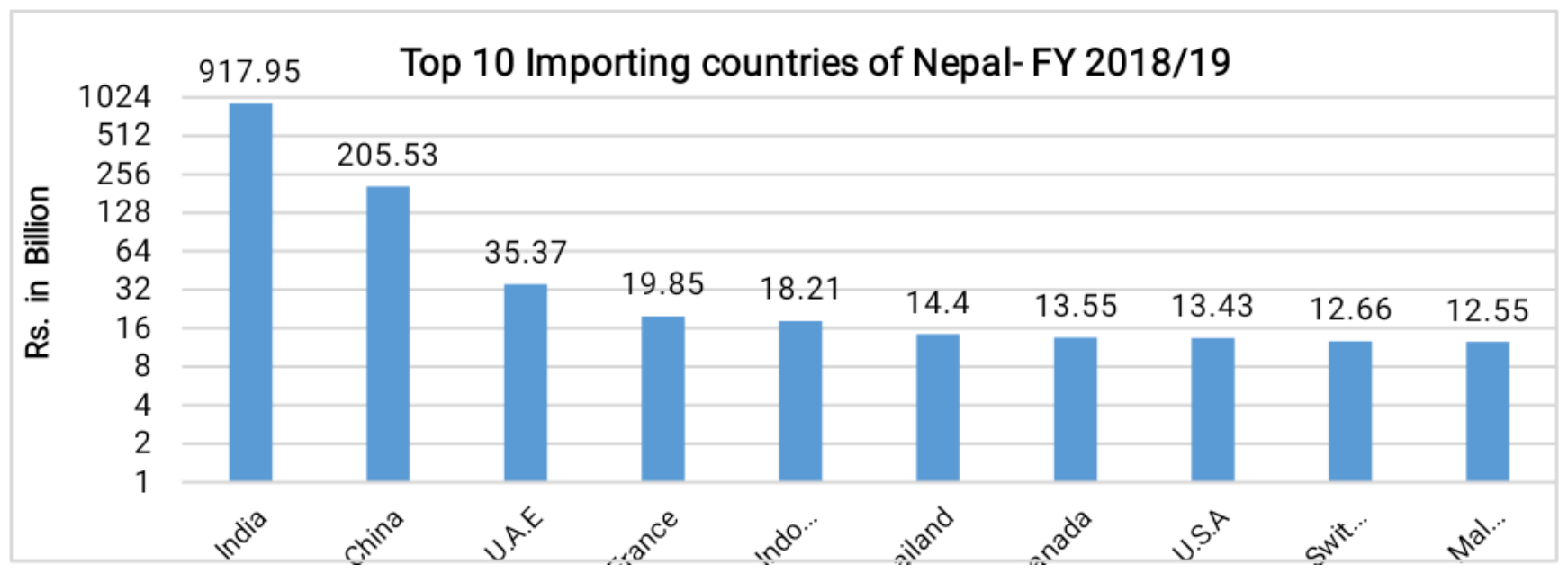

Figure 22 Top 10 Importing countries of Nepal- FY 2018/19 


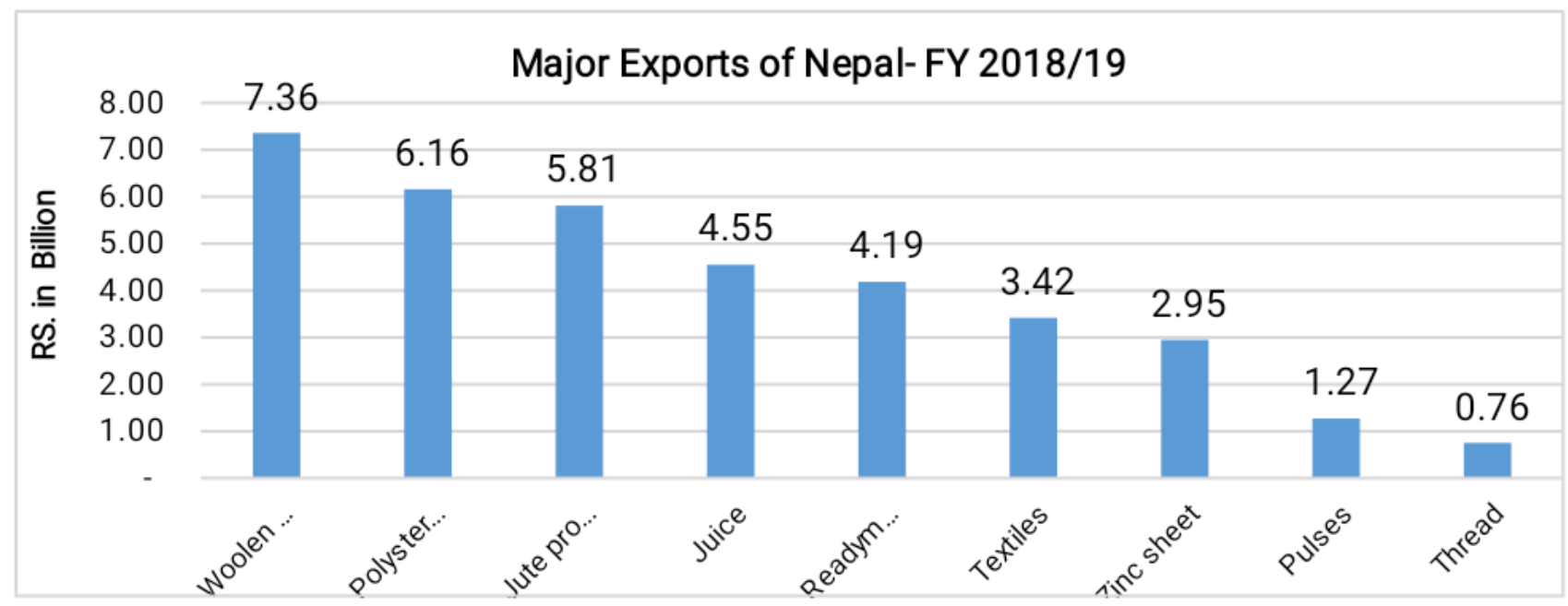

Figure 23 Major Exports of Nepal- FY 2018/19

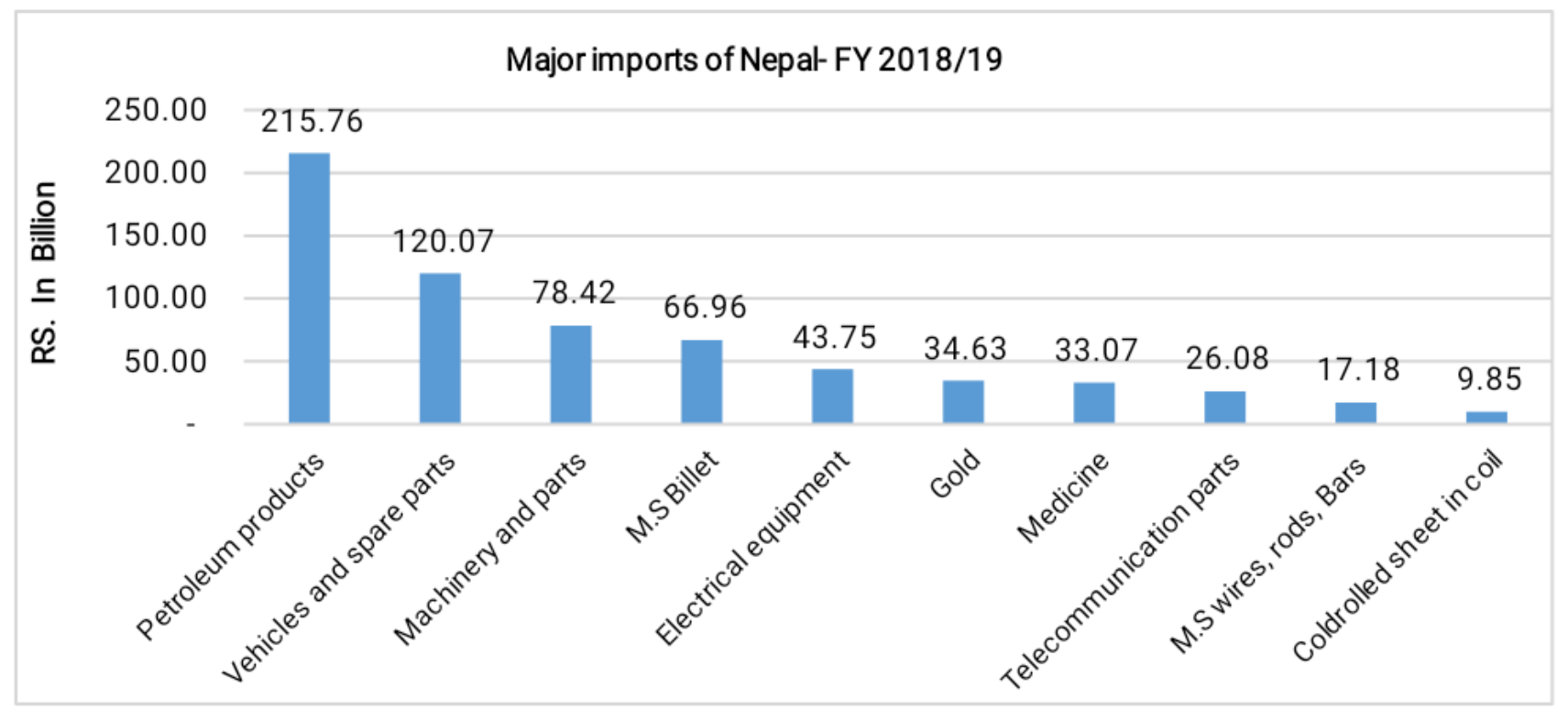

Figure 24 Major imports of Nepal- FY 2018/19

Source: (Nepal Rastra Bank, Economic Bulletin andindicators, 2020)

\section{4) Recommendations}

In globalize economy, Nepal cannot remain on segregation. Now, Nepal has trade relation with many countries of the world. Nepalese foreign trade trends and framework seems not so concrete. Gradually, increment of trade deficit shows that Nepalese trade is dominated by imports. To link the expanding trade gap, Nepal must act to expand production of local products, provide grants to the farmers, create conducive environment for the establishment of industries and rationally exploit the trade facilities. Nepal must formulate strict law against the production of goods not maintaining the standards, exploiting child as labour, and breach of contracts so that the global market could trust Nepal, and procure products without any suspicion. Analysing all the barriers in the foreign trade, this study has some suggesttions for the promotion and expansion of Nepal's foreign trade especially exports trade and ultimately economic growth of a country. Some of the suggestions are provided for incorporation in the trade promotion of Nepal as below: 
Trade deficit impede Nepalese economic growth : an analysis from review perspective

\section{Competitive Ability and Enhancement of Human Resources:}

In the modern era of globalization, Nepal needs to be competitive in the global level for which it holds some competitive advantage. Nepal does not possess comparative advantage in the sector of economies of scale, cutting-edge technology, marketing strengths, efficient production, and distribution systems but holds advantage on cheap labour. So, building of such human resources is the key for grabbing opportunities in the market. In the recent past of Nepal, human resource has become the key to success in International trade. Three areas could be identified in the context of Nepal,

- $\quad$ There is a need to enhance capacities in product innovation.

- $\quad$ Promotion of marketing skills

- $\quad$ Enhancement of trade-related expertise, analytical skills, and negotiating skills to the personnel of public sector.

\section{Co-ordination of trade with Development Strategies and Safeguards Arrangement:}

Even though Nepal has done unconditional efforts to open its economy to the greater extent, the standard results could not be generated owing to the lack of consistency between trade policies and other development policies. Thus, there is a need to coordinate trade and development strategies. No doubt, open economy is favourable to protectionism (practice of defending a country's domestic industries from foreign competition by taxing imports), free trade without any safeguards could lead a country to calamity, as has been demonstrated by the East Asian and the Latin American crisis. In this context, appropriate safeguards are recommended.

\section{Commodity and Market Diversification:}

Heavy dependence on a few low-value exports like Readymade garments and carpets has created hurdles in enhancing trading opportunities. During the year 2018/19, Nepal exported Woolen carpet, Polyester yarn, Jute products and Juices comprising almost $25 \%$ of total exports making export concentration ratio (denoted as the share of the principal export products in the total export value) high. Adequate efforts should be made to cut back export concentration ratio or to develop new areas of products or services that could be exported to the international market. There is absence of export diversification in case of Nepal. Nepal has not taken sufficient steps to develop products, identify product market and establish a link between product and market. Though the objective of product and market diversification has been indicated in plan documents as well as various policies issued by government time to time, it has not been disbursed in an efficient manner. Hence, this can be a vicinity where immediate steps should be taken to face the worldwide competition.

\section{Strong Legal Framework and New Trade Policy:}

Nepal does not possess a durable, flexible and legal framework for administering trade. The Export-Import Control Act 1957 was initiated fundamentally with the motive of controlling or prohibiting the export or import of restricted items. Moreover, this act, in the present context, seems to have lost its significance as hardly anything has been mentioned about the process of registration of export-import agencies, export promotion, sharing of information, finance, export incentives, institutional arrangements and dispute settlement (Nepal Law Commission, 2006). Therefore, this act needs to be amended, taking into consideration its uniformity with WTO provisions. Or else, a separate foreign trade act should be formulated and enacted, for making import and export more systematic by fixing and reinforcing existing acts and regulations. Furthermore, Trade policy of 1992 has been outdated in the present context of globalization and liberalization. It is critical to bring new trade policy. 
Trade deficit impede Nepalese economic growth : an analysis from review perspective

Development of Export Processing Zone:

It was in December 1990 that the government constituted a high-level working committee under the chairmanship of the Industry Minister to set up an EPZ in Kathmandu to promote export-oriented industries. An EPZ is an industrial area especially designed for export-oriented industries and it provides the facility of tax exemption on imports of raw materials needed by the manufacturers inside the region. However, the manufactured goods are not allowed to be sold in the country. Even in 1990, five products were identified which could be produced by the industries inside the EPZ: carpets, garments, leather-based products, electric and electronic goods, products based on herbs and jewellery. However, almost fifteen years have passed, and there is no sign of the creation of an EPZ yet. It is crucial that the government takes necessary steps immediately to formulate relevant laws for establishment of EPZs, and measures should be initiated to set up EPZs at appropriate locations (Dr. Bhubanesh Pant, 2005).

\section{Reliable Trade Data and Periodic Reviews:}

There is scarcity of knowledge on market information, pricing, quality, and level of competition, among others. Similarly, reliable data on trade are lacking as the figures published from one institution is different from the opposite institution. The proposed Nepal Trade Promotion Organization could be entrusted with this task of creating commodity-wise database relating to investment, production, imports and exports, among others. Timely review of performance of the country in both regional and foreign markets need to be undertaken in order to maintain the country's export thrust. Periodic policy analysis should be conducted by all relevant stakeholders in order to minimize the inherent gap between policy formulation and implementation with agreed time frames. This will enable the adoption of the corrective measures to be timely executed. According to Dr. Bhubanesh Pant, (2005), reviews thus call for capacity in the various institutions to deal with issues such as;

- Target setting

- Collection of timely and relevant data

- Analytical skills

- Information dissemination

Incentives for the promotion of export:

In 2011, the government introduced cash incentive scheme to push exports. As per the prevailing cash incentive, exporters of products with up to 30-50 percent value addition are entitled to urge 2 percent of total export revenue as cash incentive. Similarly, those with 50-80 percent value addition are speculated to get 3 percent while for over 80 percent value addition, the cash incentive has been offered at 4 percent of the full export value of a specific product. But the cash incentive distribution process is created complex that the exporters who are eligible for incentives must wander from one office to a different for the cash refund. Merely introducing cash incentives for exports in absence of a conducive investment and industrial environment within the country won't help boost the exports. Cash incentive isn't the panacea to narrow down the spiraling deficit until and unless we resolve the long running labor unrest within the industrial sector. Cash incentive distribution process isn't only lengthy but also requires a solution who deserves the inducement - producers or exporters. This confusion has thrown the complete scheme into uncertainty. Cash incentives scheme should promote not only exports, but also should specialize in creation of more employment opportunities and process for cash refund should be made simplified (South Asia Watch on Trade, Economics \& Environment, 2019) 
Trade deficit impede Nepalese economic growth : an analysis from review perspective

Priority on Agriculture and Hydropwer:

The corporate deficiencies, tax arrangement, corruption, and the small size of the market are prohibiting Nepal in fixing its problems in the trade sector. That is why, the country needs to specialize in the areas in which it can gain a competitive advantage. Nepal should step its foot on agriculture, small \& cottage industries and hydropower projects. Emphasis should be to chop the import of products which can be produced in Nepal, such as rice, grains, fruits, vegetables, etc. For instance, all things left balanced, just unquestionably reducing the import of agricultural products and by reducing petroleum imports (and substituting it with domestic hydropower) could cut Nepal's deficit to some extent. If the agricultural sector commences to become competitive to the point of being ready for export, the deficit can be reduced even more (Jagadish Prasad Bist, 2019).

\section{5) CONCLUSIONS}

Though Trade is reckoned as the engine of economic growth, there still exists a huge gap between the objective and vision. The country still depends on a relatively small bucket of exports and a few destination markets. Unmanaged infrastructure and a lack of suitable business environment fueled by heightened political instability are the primary reasons for improper industrialization in Nepal. Consequently, domestic industries have not been able to capitalize the opportunity disclosed by robust growth in domestic demands. Nepal is an agricultural country, produces and exports only primary goods and raw materials. Nepal mainly exports Pashmina products, carpets, cereals, jute etc and imports petroleum products, vehicles, machineries and so on. A nation with Trade deficit spends more on import than it earns on exports. But over time, continuous trade deficit weakens domestic industries and decreases job opportunities. So, trade deficit needs to be reduced to the minimum possible extent. Until and Unless, Nepal increases trade competitiveness formulating and adopting different policies, Nepal cannot reduce everincreasing trade deficit. Export diversification has also become demand of time.

\section{REFERENCES}

1) Achyut Wagle. (2018, August 7). Trade deficit. Retrieved from The Kathmandu Post: https://kathmandupost.com/money/2018/08/07/trade-deficit

2) Balassa, B. (1989). The importance of trade for developing countries. Directions in the World Economy, 3-31.

3) Batra, R., \& Beladi, H. (2013). The US trade deficit and the Rate of Interest. Review of International Economics, 614-626.

4) Benjamin J. Loecken . (2018, fabuary 10). Nepal extravagant Import tax. Retrieved from Grass root News: http://grassrootsnews.tv/2018/02/10/why-nepal-has-the-highest-vehicle -import-tax-in-the-world/

5) BureauofEconomicanalysis.(2020,September3). Methodologies. RetrievedfromBureau of Economic analysis: https://www.bea.gov/resources/methodologies\#national_meth

6) centre, T. a. (2019, May 30). Foreign Trade Balance of Nepal. Retrieved from Trade and export promotion centre:https://www.tepc.gov.np/

7) Dr. Bhubanesh Pant. (2005, August 1). NRB archives. Retrieved September 6, 2020, from archive nrb: https://archive.nrb.org.np/ecorev/pdffiles/vol17_art5.pdf

8) Investopedia. (2019, August 28). Expenditure method. Retrieved from Investopedia: https://www.investopedia.com/terms/e/expenditure-method.asp

9) Investopedia. (2019, August 28). Expenditure method. Retrieved from Investopedia: https://www.investopedia.com/terms/e/expenditure-method.asp 
Trade deficit impede Nepalese economic growth : an analysis from review perspective

10) Jagadish Prasad Bist. (2019, November 2). Nepal reliance on agriculture for trade deficit reduction.

RetrievedSeptember7,2020,fromTheKathmanduPost:https://kathmandupost.com/columns/2019/11/02/to reduce-the-trade-deficit-nepal-has- to-rely-on-agriculture

11) Kafle, A. (2017). Nepal's foreign trade: present trends. International Journal of Latest Engineering and Management Research (IJ LEMR), 2(11), 1-7.

12) Kenton, W. (2019, June 25). Multi-fiber arrangement. Retrieved from Investopedia: https://www.investopedia.com/terms/m/multi-fiber-arrangement.asp

13) Macro trends. (2020, July 31). Nepal inflation rate. Retrieved from Macro trends: https://www.macrotrends.net/countries/NPL/nepal/inflation-rate-cpi

14) MapsofWorld.(2019,August 1).PrimeministersofNepal.RetrievedfromMapsofWorld: https://www.mapsofworld.com/list-of/prime-ministers-nepal/

15) Nepal Carpet Manufacturer and Exporter Association. (2018, November 11). History of Carpet. Retrieved from Nepalcarpet.org: https://nepalcarpet.org/history-of-carpet/

16) Nepal Law Commission. (2006, November 24). Export and Import Control Act 1957.

RetrievedSeptember6,2020,fromLawcommission:

http://www.lawcommission.gov.np/en/archives/category/documents/prevailing- law/statutes-acts/exportand-import-control-act-2013-1957

17) NepalPlanningCommission.(2016,December3).Periodicalplan.RetrievedfromNational planning commission:https://www.npc.gov.np/en/category/periodic_plans/12

18) Nepal Rastra Bank. (2019, July 31). Annual report. Retrieved from Nepal Rastra Bank: https://www.nrb.org.np/contents/uploads/2020/08/Annual-Report-2017.18.pdf

19) Nepal Rastra Bank. (2020, April 31). Economic Bulletin and indicators. Retrieved from NRB: https://www.nrb.org.np/contents/uploads/2019/12/Macroeconomic_Indicators_of_Nepal- 2019-

11_November_2019-new.pdf

20) Nepal, G. o. (2019, May 30). Foreign trade balance of Nepal. Retrieved August 28, 2020, from Trade and export promotion centre: https://www.tepc.gov.np/

21) Nepal-India Chamber of Commerce and Industry. (2019, July 31). Trade statistics. Retrieved from Nepal-India Chamber of Commerce and Industry:

https://www.nicci.org/pdf/10.\%20Comparison\%20of\%20Nepal's\%20Annual\%20Total\%20E xports\%20vs\%20Total\%20Import\%20of\%20Petroleum\%20Products.pdf

22) New Business Age . (2019, May 28). Import of Vehicles. Retrieved from New businss age: https://www.newbusinessage.com/Articles/view/10778\#: :text=Data\%20collected\%20fro m\%201989\%20to,as\%20of\%20FY\%202017\%2F18.

23) Prasain, K. (2019, September 16). Export of Nepali Garment hits 13-year high.Retrieved August 31,2020, from The Kathmandu Post https://kathmandupost.com/money/2019/09/16/export-of-nepali-readymade-garment- hits-13-year-high 24) Silwal, R. (2008). The causes of trade deficit in Nepal. The Hague, Netherlands: Institute of Social studies(ISS).

25) South Asia Watch on Trade, Economics \& Environment. (2019, November 12). sawtee. Retrieved from Cash Incentives on Export: https://www.sawtee.org/sawtee-in-media/is- cash-incentive-for-exports-aflawed-policy $\% \mathrm{C} 2 \% \mathrm{~A} 0 . \mathrm{html}$

26) Statistica. (2020, August 1). Nepal: Unemployment rate. Retrieved from Statistica: https://www.statista.com/statistics/422507/unemployment-rate-in-nepal/ 
Trade deficit impede Nepalese economic growth : an analysis from review perspective

27) Sun koshi craft. (2019, september 23). Chyangra Pashmina. Retrieved from Nepalfine Pashmina: http://nepalfinepashmina.com/about-chyangra-pashmina

28) Tejvan Pettinger. (2017, October 8). Imports and Inflation. Retrieved September 4, 2020, from Economics Help: https://www.economicshelp.org/blog/1491/economics/imports- and-inflation/

29) Trade and Export Promotion Centre. (2019, July 17). Export-Import data bank. Retrieved from Trade and Export Promotion Centre:

http://www.efourcore.com.np/tepcdatabank/commoditywise.php?txtmode=search

30) Trade and export promotion centre. (2019, May 30). Foreign trade balance of Nepal. Retrieved from Trade and export promotion centre: http://www.efourcore.com.np/tepcdatabank/ 31) Trade and Export Promotion Centre. (2019, July 16). Hand knotted woolen product of Nepal. Retrieved from Trade and Export Promotion Centre: https://www.tepc.gov.np/major_products/full_content

32) TradeandExportPromotionCentre.(2019,July 17). WoolenCarpet.RetrievedfromTrade and Export Promotion Centre: https://www.tepc.gov.np/major_products/full_content/hand-knotted-woolen-carpet-ofnepal.

33) TradeandExportPromotionCentre.(2019,July 17).Woolencarpets.RetrievedfromTrade and Export Promotion Centre: https://www.tepc.gov.np/major_products/full_content/hand-knotted-woolen-carpet-ofnepal

34) Trade and Export Promotion Centre. (2020, July 31). Glimpse of Nepal's foreign trade. Retrieved from Trade andExportPromotion Centre:https://www.tepc.gov.np/pages/tepc- publication

35) Trading Economics. (2020, August 31). Nepal Imports. Retrieved from Trading Economics: https://tradingeconomics.com/nepal/imports\#: :text=Imports\%20in\%20Nepal\%20averag ed\%2044934.88,NPR\%20in\%20October\%20of\%202001.\&text=Nepal\%20Imports\%20\%2D\% 20values $\% 2 \mathrm{C} \% 20$ historical\%20data,updated $\% 20$ on $\% 20$ September\%20of\%202020.

36) Udit Misra. (2019, November 6). Trade deficit. Retrieved from Indian Express: https://indianexpress.com/article/explained/explained-what-is-trade-deficit-and-what- does-it-signify$\underline{6104561 /}$

37) World Bank. (2019). Trade (\% of GDP)-Nepal. Retrieved August 29, 2020, from World Bank indicator: https://data. worldbank.org/indicator/NE.TRD.GNFS.ZS?end=2019\&locations=NP\&start=19 60\&view=chart 38) World bank. (2020, September 02). Trading economics. Retrieved from Trading economics: https://tradingeconomics.com/nepal/trade-percent-of-gdp-wb-data.html 39) World Trade Organization. (2016, 07 29). WTO Membership. Retrieved from World Trade Organization: https://www.wto.org/english/thewto_e/whatis_e/tif_e/org6_e.htm 